\title{
KWESTIONARIUSZ REAKCJI PRZYSTOSOWAWCZYCH (KRP) - POLSKA ADAPTACJA REACTIONS TO IMPAIRMENT AND DISABILITY INVENTORY - RIDI H. LIVNEHA I R.F. ANTONAKA
}

\begin{abstract}
Byra Stanisława, Kirenko Janusz, Kwestionariusz Reakcji Przystosowawczych (KRP) - polska adaptacja Reactions to Impairment and Disability Inventory - RIDI H. Livneha i R.F. Antonaka [Adaptive Responses Inventory Questionnaire - Polish Adaptation of Reactions to Impairment and Disability Inventory - RIDI H. Livneha i R.F. Antonaka]. Studia Edukacyjne nr 40, 2016, Poznań 2016, pp. 229260. Adam Mickiewicz University Press. ISSN 1233-6688. DOI: $10.14746 /$ se.2016.40.14
\end{abstract}

The paper presents Polish adaptation of Reactions to Impairment and Disability Inventory (RIDI), measurement scale developed by H. Livneh and R. F. Antonak, in Polish referred to as Kwestionariusz Reakcji Przystosowawczych (KRP) [Adaptive Responses Inventory Questionnaire]. It describes the conceptual grounds for the tool, stages of the adaptation process and psychometric properties of the scale. Based on the analysis of results of a study conducted on a group of 940 individuals with acquired disabilities (after spinal cord injury, lower extremity amputation or multiple sclerosis) and chronic illnesses (diabetes, cardiovascular diseases, cancer and rheumatoid arthritis), reliability, stability and accuracy of the questionnaire were verified. Results of the factor analysis provided grounds for selection of 8 factors - categories of adaptive responses, in accordance with the original scale. Conducted adaptation works have confirmed satisfactory psychometric properties of the questionnaire which may be used in Poland to diagnose various categories of non-adaptive and adaptive responses after suffering a deterioration of ability or development of a chronic illness.

Key words: acquired disability, chronic illness, adaptive responses, Polish adaptation of the questionnaire

\section{Wprowadzenie}

Przystosowanie osób z niepełnosprawnością stanowi przedmiot zainteresowania kilku już generacji badaczy, którzy z większym lub mniejszym 
powodzeniem próbują uchwycić skomplikowaną naturę tego zjawiska. W ramach wypracowywania coraz to lepszych podejść analitycznych badacze wysuwali kolejne modele, teorie, czy koncepcje przybliżające istotę przystosowania do życia po nabyciu trwałych ograniczeń w zdrowiu czy sprawności. Na przestrzeni długiego już czasu stworzono szereg definicji przystosowania do życia z niepełnosprawnością, w zdecydowanej mierze sprawozdawczych, nierzadko o charakterze fragmentarycznego ujęcia jednego z jego elementów, czy akcentowania wybranych przejawów tego zjawiska $\mathrm{w}$ przyjętym obszarze funkcjonowania jednostki. Nierzadkim zabiegiem badawczym jest przyjmowanie jedynie definicji operacyjnej obejmującej wyselekcjonowane wskaźniki empiryczne, abstrahujące od jakiegokolwiek ugruntowania teoretycznego. Znajduje to konsekwencje w poważnych trudnościach interpretacyjnych zarówno w zakresie struktury, jak i funkcji przystosowania. Zauważalny brak tzw. definicji równościowych, całościowych, ukazujących spójną charakterystykę przystosowania u osób dotkniętych niepełnosprawnością wskazuje na stosunkowo niewielki postęp w rozumieniu zjawiska analizowanego od ponad pięćdziesięciu lat. Przyczyny tego stanu rzeczy można odnajdywać w samej jego naturze, nieuchwytnej, skomplikowanej, w znaczącym stopniu nieprzewidywalnej, podlegającej oddziaływaniu szeregu zmiennych zarówno indywidualnych, jak i społecznych. Istotne znaczenie ma również czasowy wymiar przystosowania. Temporalne osadzenie zjawiska tłumaczy jego dynamikę zmieniającą się pod wpływem przeobrażeń $\mathrm{w}$ wymogach otoczenia oraz $\mathrm{w}$ samej jednostce wraz $\mathrm{z}$ upływem czasu od nabycia ograniczeń w zdrowiu czy sprawności. Nie sposób pominąć przyczyny wciąż słabej konceptualizacji przystosowania $\mathrm{w}$ postaci ciągle ograniczonych weryfikacji tworzonych modeli czy teorii tego zjawiska, co uniemożliwia lub znacząco utrudnia doskonalenie samego procesu definiowania.

Wynikająca z zasygnalizowanych uwarunkowań wieloznaczność termi$\mathrm{nu}$ "przystosowanie do życia z niepełnosprawnością" podlega ponadto określonej interpretacji w kontekście ewolucji poglądów na temat psychospołecznych konsekwencji nabycia trwałych uszkodzeń $\mathrm{w}$ zdrowiu czy sprawności ${ }^{1}$. Przełomowe przeobrażenia $w$ sposobie ich wyjaśniania odzwierciedlone są $\mathrm{w}$ teoretycznych modelach (w zróżnicowanym stopniu

1 Por. S. Byra, Przystosowanie do życia z niepetnosprawnościa ruchowa $i$ choroba przewlekta. Struktura i uwarunkowania, Lublin 2012, s. 51; tejże, Ewolucja pogladów dotyczacych przystosowania do życia osób z nabyta niepetnosprawnościa, Człowiek - Niepełnosprawność - Społeczeństwo, 2006, 2(4), s. 54-60; J. Kirenko, Niektóre uwarunkowania psychospołecznego funkcjonowania osób z uszkodzeniem rdzenia kręgowego, Lublin 1995, s. 33-41; tegoż, Psychospołeczne przystosowanie osób z paraplegia, Lublin 1991, s. 21-33. 
i zakresie empirycznie zweryfikowanych): linearnych, wahadłowych, ekologicznych oraz interakcyjnych. Wyrażają one swoiste punkty zwrotne w spojrzeniu na niepełnosprawność i reagowanie na jej doznanie. W uogólnionym sensie można je wyrazić $w$ następujących założeniach: 1) przystosowanie ma charakter linearny, polega na sekwencyjnym następowaniu po sobie stadiów, które pojawiają się wraz z upływem czasu od nabycia trwałych ograniczeń; jest to proces niejako samoczynnie ukierunkowany na progres, warunkiem doświadczenia kolejnego stadium jest osiągnięcie wcześniejszego; efekt finalny następuje $\mathrm{w}$ rezultacie bezkolizyjnego przechodzenia przez wszystkie założone stadia (modele linearne); 2) przystosowanie wyraża się w doświadczaniu powtarzających się cykli przybliżania i wycofywania w zmaganiu się z konsekwencjami nabytej niepełnosprawności; proces ten ma charakter odwracalny, dopuszcza się w nim płynność granic między poszczególnymi stadiami; efekt adaptacyjny jest skutkiem powtarzających się doświadczeń, przeżyć, reakcji, zachowań, które wyznaczają stopień integracji doznanych ograniczeń, straty i stopniowo odbudowywanej tożsamości (modele wahadłowe); 3) przystosowanie stanowi wypadkową relacji jednostki z otoczeniem (modele ekologiczne); 4) przystosowanie jest procesem podlegającym oddziaływaniu wielu zmiennych wchodzących ze sobą $\mathrm{w}$ interakcje tworząc złożone konfiguracje czynników usytuowanych w jednostce i świecie zewnętrznym (modele interakcyjne) ${ }^{2}$.

Wychodząc $\mathrm{z}$ założeń zawartych $\mathrm{w}$ przytoczonych modelach oraz bazując na dotychczasowych ich empirycznych weryfikacjach, można wyakcentować kilka istotnych ustaleń $\mathrm{w}$ zakresie wyjaśniania zjawiska przystosowania do życia z niepełnosprawnością. Po pierwsze, nie istnieją dowody na przyjęcie linearnej natury tego procesu, co daje podstawę do zanegowania założenia o konieczności przechodzenia przez ustalony schemat etapów w kierunku osiągnięcia stadium pełnego przystosowania. Sekwencyjność faz (odzwierciedlających spektrum negatywnych stanów emocjonalnych) zaobserwowana $\mathrm{w}$ okresie bezpośrednio następującym po nabyciu niepełnosprawności wraz z upływem czasu nie została potwierdzona ${ }^{3}$.

2 H. Livneh, R.F. Antonak, Psychosocial adaptation to chronic illness and disability, Gaithersburg 1997, s. 49; E. Kendall, N. Buys, An integrated model of psychosocial adjustment following acquired disability, Journal of Rehabilitation, 1998, 64(3), s. 16-18; H. Livneh, P. Parker, Psychological adaptation to disability: Perspectives from chaos and complexity theory, Rehabilitation Counseling Bulletin, 2005, 49(1), s. 18-21; S. Byra, Przystosowanie do życia z niepetnosprawnościq ruchowa, s. 54; tejże, Ewolucja poglądów dotyczących przystosowania do życia, s. 55-61.

${ }^{3}$ Np. J.S. Krause, Changes in adjustment after spinal cord injury: A 20-year longitudinal study, Rehabilitation Psychology, 1998, 43(1), s. 49. 
Po drugie, teoretycznie spójna wahadłowa natura przystosowania wspierana danymi z analiz jakościowych nakreśla cyrkularny obraz zjawiska, sygnalizowany już we wczesnych etapach badań nad niepełnosprawnością. Uznanie powtarzalności pewnych reakcji, przeżyć, doświadczeń $\mathrm{w}$ trakcie długofalowego procesu przystosowania dostarcza nowego (w porównaniu z podejściem tradycyjnym - linearnym) rozumienia ich natury, niejednoznacznej w swym wymiarze. Odrzuca się tym samym interpretację reakcji przejawianych $\mathrm{w}$ czasie niezgodnym $\mathrm{z}$ oczekiwaniami $\mathrm{w}$ kategorii patologiczności, np. nawracającego żalu po stracie, chronicznego smutku, braku akceptacji ograniczeń utrudniających osiąganie przyjętych celów. Wahadłowość przystosowania do życia $\mathrm{z}$ niepełnosprawnością wyraża się $\mathrm{w}$ swoistym przeplataniu się stopniowo zachodzących przeobrażeń $\mathrm{w}$ akceptowanej hierarchii wartości z opłakiwaniem strat poniesionych wraz z nabyciem trwałych ograniczeń i nieustannym przezwyciężaniem poczucia niepełnowartościowości i niższości. Nie tyle upływ czasu, co zwiększający się zakres zmian $\mathrm{w}$ preferowanych wartościach, modyfikacja celów dostosowanych do obecnych możliwości osłabia tęsknotę za wcześniejszą wizją życia, siebie i posiadanego potencjału. Zakres tych przeobrażeń jest zaś kwestią wysoce zindywidualizowaną ${ }^{4}$.

Po trzecie, wyjaśnianie permanentnego charakteru przystosowania u osób z nabytą niepełnosprawnością dokonywane jest w kontekście jego powiązań z szerokim zakresem czynników: socjodemograficznych, osobowościowych, społecznych, środowiskowych i bezpośrednio związanych z posiadanymi dysfunkcjami. Ujawniana jest złożoność samej struktury przystosowania, związków pomiędzy poszczególnymi jego elementami, jak również tworzonych konfiguracji powiązań $\mathrm{z}$ różnymi $\mathrm{w}$ swej naturze zmiennymi ${ }^{5}$.

${ }^{4} \mathrm{M}$. Bishop, Quality of life and psychosocial adaptation to chronic illness and acquired disability: Preliminary analysis of a conceptual and theoretical synthesis, Rehabilitation Counseling Bulletin, 2005a, 48(3), s. 222-226; tegoż, Quality of life and psychosocial adaptation to chronic illness and acquired disability. A conceptual and theoretical synthesis, Journal of Rehabilitation, 2005b, 71(1), s. 610; E. Kendall, N. Buys, An integrated model of psychosocial adjustment, s. 19; J. Kirenko, Niektóre uwarunkowania psychospołecznego funkcjonowania osób, s. 62; K.C. Keany, R.L. Glueckauf, Disability and value changes: An overview and analysis of acceptance of loss theory, Rehabilitation Psychology, 1993, 38(2), s. 202-204.

${ }^{5}$ M.in. I.R. Molton i in., Psychosocial factors and adjustment to chronic pain in spinal cord injury: Replication and cross-validation, Journal of Rehabilitation Research and Development, 2009, 46(1), s. 36; M. Bishop, Quality of life and psychosocial adaptation to chronic illness, s. 9; E. Martz $\mathrm{i}$ in., Predictors of psychosocial adaptation among people with spinal cord injury or disorder, Archives of Physical Medicine and Rehabilitation, 2005, 86(6), s. 1188; H. Livneh, R.F. Antonak, J. Gerhardt, Psychosocial adaptation to amputation: the role of sociodemographic variables, disability related factors and coping strategies, International Journal of Rehabilitation Research, 1999, 22(1), s. 26-27. 
Po czwarte, problemy metodologiczne $\mathrm{w}$ postaci m.in.: ateoretyczności stosowanych wskaźników przystosowania lub ich słabego ugruntowania teoretycznego, wykorzystywania narzędzi pomiarowych teoretycznie nieosadzonych, o niezadowalających właściwościach psychometrycznych, umożliwiających uchwycenie jedynie ograniczonego zakresu reagowania przystosowawczego, czy też prowadzenia badań na stosunkowo niewielkiej i niehomogenicznej próbie, znacząco utrudniają wnikliwe poznanie rzeczywistej natury zjawiska przystosowania do życia z niepełnosprawnością.

\section{Teoretyczne podstawy kwestionariusza}

\section{Przystosowanie w ujęciu H. Livneha i R.F. Antonaka}

Prezentowany kwestionariusz został opracowany do oceny różnych sposobów reagowania na doświadczane ograniczenia związane z nabytą niepełnosprawnością lub chorobą przewlekłą. Opiera się na założeniach skonstruowanego przez autorów modelu przystosowania do życia z niepełnosprawnością i chorobą przewlekłą. Model ten na przestrzeni lat ulegał znaczącym przeobrażeniom na podstawie kolejnych eksploracji empirycznych, dających podstawę do zweryfikowania wcześniej wysuniętych założeń ${ }^{6}$. Opracowane narzędzie pozwala na weryfikację jednego $\mathrm{z}$ jego elementów - reakcji przystosowawczych, które osoba przejawia po nabyciu trwałych uszkodzeń w zdrowiu czy sprawności. Przyjęte ich rozumienie jest konsekwencją kilku założeń wysuniętych przez H. Livneha i R.F. Antonaka do wyjaśniania zjawiska psychospołecznej adaptacji. Wyjściowa w tym względzie teza przejęta $\mathrm{z}$ modeli ekologicznych zakłada, iż sposób reagowania jednostki na sytuacje trudne osadzony jest w relacji jednostka - otoczenie. W tym kontekście psychospołeczna adaptacja osób z nabytą niepełnosprawnością czy chorobą przewlekłą jest ujmowana w kategorii procesu ukierunkowanego na przywrócenie równowagi między jednostką i otoczeniem. Zgodnie z poglądami autorów reprezentujących podejście interakcyjne, adaptacja do życia z niepełnosprawnością jest skomplikowanym procesem powrotu do równowagi, którego charakterystyka ujawnia się w swoistej

${ }^{6}$ Zob. H. Livneh, R.F. Antonak, Reactions to disability: An empirical investigation of their nature and structure, Journal of Applied Rehabilitation Counseling, 1990, 21(4), s. 14-17; H. Livneh, R. F. Antonak, Temporal structure of adaptation to disability, Rehabilitation Counseling Bulletin 1991, vol. 34(2), s. 299-306; H. Livneh, R.F. Antonak, Psychosocial adaptation to chronic illness and disability, s. 55; H. Livneh, R.F. Antonak, Psychosocial adaptation to chronic illness and disability: A primer for counselors, Journal of Counseling and Development 2005, 83(1), s. 16-17; $\mathrm{H}$. Livneh, Psychosocial adaptation to chronic illness and disability: A conceptual framework, Rehabilitation Counseling Bulletin 2001, 44(1), s. 154. 
kombinacji reakcji przystosowawczych, pewnych ich związkach będących konsekwencją oddziaływania szeregu czynników intra- i ekstrapersonalnych pozostających ze sobą w interakcji .

Interakcyjny model psychospołecznej adaptacji do chronicznej choroby i niepełnosprawności został zaprezentowany przez H. Livneha w 2001 roku, będący znaczącą modyfikacją jego pierwotnej wersji spopularyzowanej we wcześniejszych pracach ${ }^{8}$. Na model adaptacji składają się trzy główne elementy składowe: zmienne poprzedzające (zmienne wywołujące i kontekstualne), proces psychospołecznej adaptacji (reakcje przystosowawcze i zmienne kontekstualne), wyniki procesu w postaci wielowymiarowo ujętej jakości życia (ryc. 1).

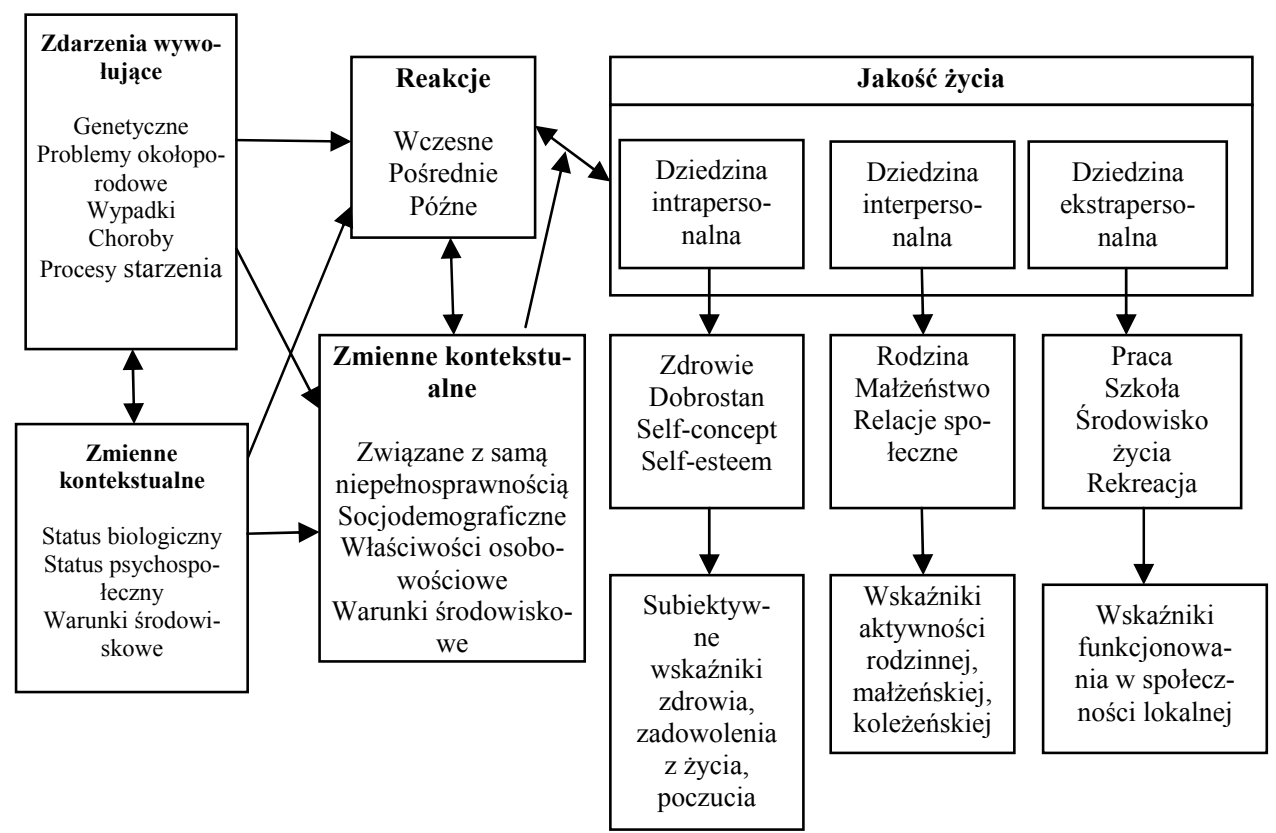

Ryc. 1. Model psychospołecznej adaptacji do chronicznej choroby i niepełnosprawności H. Livneha i R.F. Antonaka (opracowano na podstawie: H. Livneh, Psychosocial adaptation to chronic illness and disability: A conceptual framework, Rehabilitation Counseling Bulletin, 2001, 44(1), s. 155)

${ }^{7}$ H. Livneh, S.M. Lott, R.F. Antonak, Patterns of psychosocial adaptation to chronic illness and disability: a cluster analytic approach, Psychology Health and Medicine, 2004, 9(4), s. 412-415.

${ }^{8}$ H. Livneh, R.F. Antonak, Reactions to disability, s. 14-17; H. Livneh, R.F. Antonak, Temporal structure of adaptation to disability, Rehabilitation Counseling Bulletin, 1991, 34(2), s. 299306; H. Livneh, R.F. Antonak, Psychosocial adaptation to chronic illness and disability; Por. S. Byra, $H$. Livneha $i$ R. Antonaka koncepcja adaptacji do życia z niepetnosprawnościa, Niepełnosprawność i Rehabilitacja, 2008, 4, s. 3-21. 


\section{Zmienne poprzedzające. Procesy. Rezultaty}

H. Livneh i R.F. Antonak ${ }^{9}$ wprowadzają rozróżnienie między adaptacją i przystosowaniem. Adaptacja traktowana jest jako dynamiczny proces, w którym osoba ujawnia określone reakcje przystosowawcze, mogące przyjąć charakter adaptacyjny lub nieadaptacyjny. Przyjmuje postać procesu hierarchicznego (nie linearnego), którego przebieg wyraża swoiste kontinuum rozciągające się od reakcji typowo nieprzystosowawczych po wyraźnie adaptacyjne. Reakcje przystosowawcze/nieprzystosowawcze to pewne sposoby reagowania na ograniczenia i ich konsekwencje oraz na sytuacje trudne z nimi związane, które jednostka ujawnia w procesie adaptacji. Sposób reagowania nie jest jednak osadzany $\mathrm{w}$ ramach etapowości/stadialności. Nadany tym reakcjom wymiar temporalny - "reakcje wczesne”, "reakcje pośrednie”, ,reakcje późne” określa ich specyfikację ujawniającą się w większym stopniu w danym czasie po nabyciu niepełnosprawności. Nie ustala natomiast czasowego ich występowania i linearnego następstwa. Przystosowanie ujmowane jest jako jedna $\mathrm{z}$ tzw. reakcji późnych ${ }^{10}$. Długotrwały proces przystosowania obejmuje szereg złożonych sytuacji, okoliczności, zdarzeń i doświadczeń, które wywołują reakcje o niezwykle zróżnicowanym charakterze, niejednoznacznym ładunku emocjonalnym, niemożliwym do schematycznego ustalenia kierunku. Reakcje typowo adaptacyjne mogą w różnych okresach i zróżnicowanych konfiguracjach przeplatać się z reagowaniem wyraźnie nieprzystosowawczym. U podstaw temporalnych określeń poszczególnych grup reakcji znajduje się przekonanie o umacniających się wraz z upływem czasu mechanizmach adaptacyjnych, zwiększających (ale nie determinujących) szanse na pomyślny przebieg adaptacji w postaci nasilających się tzw. reakcji późnych - akceptacji poznawczej i emocjonalno-behawioralnej. Nie oznacza to jednocześnie, iż tzw. reakcje wczesne nie wystąpią w późniejszych okresach. Ich obecność i nawet wysokie nasilenie może być wywołane przez bodźce bezpośrednio lub pośrednio związane z konsekwencjami nabytej niepełnosprawności, ale na tyle silne, że ponownie zakłócające czasowo przywróconą równowagę psychospołeczną ${ }^{11}$. Częstotliwość, natężenie i zakres reakcji określanych jako „wczesne”, „pośrednie” i „późne”, charakterystycznych dla danego czasu, tworzy ich złożoną konfigurację $\mathrm{w}$ znaczącym stopniu kształtowaną przez szereg

${ }^{9}$ H. Livneh, R.F. Antonak, Psychosocial adaptation to chronic illness and disability, s. 67.

${ }^{10}$ Por. S. Byra, Przystosowanie do życia z niepetnosprawnościa ruchowa, s. 121.

$11 \mathrm{H}$. Livneh, R.F. Antonak, Temporal structure of adaptation to disability, Rehabilitation Counseling Bulletin, 1991, 34(2), s. 301; H. Livneh, R.F. Antonak, Reactions to impairment and disability inventory users' manual - unpublished manuscript 2008. 
uwarunkowań tkwiących w jednostce i środowisku oraz w cechujących je interakcjach. Zatem, reakcje o nieprzystosowawczym charakterze stanowią nierzadko nieodłączną część długofalowego procesu psychospołecznej adaptacji, współwystępując z reakcjami pożądanymi, o naturze wyraźnie konstruktywnej, prorozwojowej12.

Natomiast, na podstawie dominacji określonych reakcji przystosowawczych (adaptacyjnych, nieadaptacyjnych) można wnioskować o pomyślnym/niepomyślnym przebiegu procesu adaptacji u osoby. Nasilenie reakcji pożądanych w postaci akceptacji poznawczej (Akceptacja) czy emocjonalnobehawioralnej (Przystosowanie) wskazuje na tzw. adaptację pozytywną. Efekty adaptacyjne utożsamiane są tutaj z wysokim natężeniem akceptacji poznawczej i emocjonalno-behawioralnej, wskazującym, iż jednostka niejako zespoliła posiadane ograniczenia $\mathrm{z}$ obrazem siebie, zarówno jednostkowym jak i społecznym, ale też zintegrowała się ze społecznością, wykonując codzienne działania zgodnie $\mathrm{z}$ przyjmowanymi rolami społecznymi mimo posiadanych ograniczeń. Przewaga natomiast reakcji nacechowanych negatywnie, np. niepokoju, zaprzeczania, depresji, świadczy o niepomyślnym przebiegu procesu adaptacji (tzw. negatywnej adaptacji). Ich nasilone przejawianie jest wskaźnikiem niepożądanych efektów adaptacyjnych ${ }^{13}$. Psychospołeczna adaptacja osób z nabytymi ograniczeniami w zdrowiu czy sprawności, będąc procesem wielowymiarowym, kompleksowym, dynamicznym i hierarchicznym, jest stopniowym przybliżaniem się do optymalnego dla danej osoby stopnia zgodności między jej możliwościami a wymogami otoczenia $^{14}$.

\section{Oryginalna wersja kwestionariusza}

Oryginalna wersja kwestionariusza została zaprezentowana przez autorów w 1990 roku jako Inwentarz Reakcji na Uszkodzenie i Niepełnosprawność (Reactions to Impairment and Disability Inventory - RIDI). Z założenia, narzędzie to miało mierzyć w sposób wielowymiarowy reakcje na ograniczenia wynikające $\mathrm{z}$ nabycia uszkodzenia organizmu i niepełnosprawności. Zasadność i potrzebę jego skonstruowania oparli na następujących argu-

\footnotetext{
12 Por. H. Livneh, E. Martz, Coping strategies and resources as predictors of psychosocial adaptation among people with spinal cord injury, Rehabilitation Psychology, 2014, 59(3), s. 330.

${ }^{13} \mathrm{H}$. Livneh, E. Martz, T. Bodner, Psychosocial adaptation to chronic illness and disability: A preliminary study of is factorial structure, Journal of Clinical Psychology in Medical Settings, 2006, 13(3), s. 252.

${ }^{14}$ H. Livneh, R.F. Antonak, Psychosocial adaptation to chronic illness and disability, s. 43.
} 
mentach: a) dotychczasowe stosowanie jednowymiarowych konstruktów do ujęcia zjawiska przystosowania do życia z niepełnosprawnością; b) dokonywanie pomiaru przystosowania $\mathrm{w}$ stosunkowo niewielkich próbach, ograniczających się do pojedynczych/specyficznych rodzajów niepełnosprawności; c) wykorzystywanie czasochłonnych i obszernych technik typu Q-sort ${ }^{15}$.

Punktem wyjścia przy konstruowaniu nowego narzędzia była analiza dotychczasowej literatury na temat przystosowania do konsekwencji traumatycznych zdarzeń, różnych kryzysów życiowych, szczególnie związanych $\mathrm{z}$ nabyciem trwałej niepełnosprawności lub chorób zagrażających życiu. Dokonano również przeglądu najczęściej stosowanych narzędzi do pomiaru sposobów przystosowywania się w sytuacjach kryzysowych, przełomowych, wynikających z poważnych ograniczeń w zdrowiu i sprawności. Ponadto, przeprowadzono wywiady z kilkoma specjalistami z zakresu rehabilitacji. W wyniku tych zabiegów poznawczych autorzy wyodrębnili ponad 300 twierdzeń wyrażających różne sposoby reagowania na niepełnosprawność. W pierwszym etapie ich analizy wyeliminowano itemy uznane za zbędne, niejasne, niejednoznaczne lub specyficzne tylko dla jednej, konkretnej grupy osób z niepełnosprawnością. Niektóre twierdzenia zostały zaś przeformułowane $\mathrm{w}$ celu lepszego uchwycenia istoty danej reakcji. Rezultatem tej procedury było stworzenie listy 200 itemów, które zostały na podstawie literatury przyporządkowane do 8 typów reakcji przystosowawczych: szok (Sz), niepokój $(\mathrm{N})$, zaprzeczanie $(\mathrm{Z})$, depresja $(\mathrm{D})$, uwewnętrzniony gniew (UG), uzewnętrzniona wrogość (UW), akceptacja (A) i przystosowanie $(\mathrm{P})$. Dokonano ponownej selekcji itemów, przeredagowane lub odrzucone zostały twierdzenia: a) $\mathrm{w}$ dalszym ciągu nie dość precyzyjnie oddające naturę danej reakcji; b) których treść dawałaby możliwość zakwalifikowania reakcji do więcej niż jednej kategorii, np. szoku i zaprzeczania jednocześnie. Ostatecznie eksperymentalna wersja kwestionariusza liczyła 143 itemy i została poddana ocenie przez 12 sędziów kompetentnych (znanych ekspertów i psychologów rehabilitacji) według następujących kryteriów: a) zasadność przyporządkowania itemu do danej kategorii reakcji; b) na ile dany item oddaje istotę reakcji, do kategorii której został przypisany. Sędziów kompetentnych poproszono również o sformułowanie uwag, sugestii w odniesieniu do poszczególnych itemów opisujących dane kategorie reakcji oraz dodanie twierdzeń nieuwzględnionych na przedkładanej im liście, a niezbędnych do pełnego zobrazowania przystosowania po nabyciu trwałych uszkodzeń w zdrowiu czy sprawności. Na podstawie odpowiedzi i sugestii sędziów

${ }^{15}$ H. Livneh, R.F. Antonak, Reactions to disability, s. 13-15. 
kompetentnych, a także po uwzględnieniu uwag pochodzących z indywidualnych wywiadów z osobami z różnymi typami niepełnosprawności fizycznej i choroby przewlekłej utworzono listę 90 itemów. Przygotowana $\mathrm{w}$ ten sposób ostateczna wersja kwestionariusza została poddana sprawdzeniu pod względem właściwości psychometrycznych. Badania przeprowadzono wśród 214 osób doświadczających różnych typów niepełnosprawności fizycznej i choroby przewlekłej. Grupa badanych obejmowała 80 kobiet i 134 mężczyzn w wieku od 16 do 83 lat $(M=43,9, S D=17,9)$. Największą liczbę badanych stanowiły osoby samotne (39,3\%) i pozostające w małżeństwie (36,0\%) (osoby rozwiedzione - 12,6\% i będące w separacji $3,3 \%)$. Przyczyny występujących u nich niepełnosprawności to: uszkodzenie rdzenia kręgowego (34,6\%), naczyniowe uszkodzenie mózgu (12,1\%), miażdżyca $(7,0 \%)$, zawał serca $(7,05 \%)$, amputacje $(6,01 \%)$. Ogółem badani wskazali na około 30 typów doświadczanej niepełnosprawności, która u większości z nich wystąpiła między 17. a 50. rokiem życia. Czas trwania niepełnosprawności wahał się $\mathrm{u}$ badanych od 1 . miesiąca do 64 lat $(\mathrm{M}=11,5$; $\mathrm{SD}=10,5)^{16}$

W pierwszych badaniach nad eksperymentalną wersją kwestionariusza respondenci trzykrotnie odnosili się do każdego itemu: najpierw szacowali stopień, $\mathrm{w}$ jakim przejawiali daną reakcję $\mathrm{w}$ przeszłości, $\mathrm{w}$ okresie bezpośrednio następującym po nabyciu uszkodzenia lub pogorszeniu stanu zdrowia, w drugiej kolejności określali stopień ujawniania danej reakcji w teraźniejszym czasie, wyłączając jednak ostatni miesiąc. $W$ trzecim podejściu oceniali stopień doświadczania poszczególnych reakcji obecnie, tj. $\mathrm{w}$ ciągu ostatniego miesiąca. Przyjęcie takiej procedury zostało uznane przez autorów za konieczne, w celu oddzielenia odpowiedzi odnoszących się do przeszłych i teraźniejszych reakcji. Dawało to możliwość kontrolowania prawdopodobnego nachodzenia na siebie teraźniejszych, krótkotrwałych reakcji, zmian nastroju, reagowania na krótkotrwałe zdarzenia losowe na reakcje bardziej trwałe związane z pojawieniem się niepełnosprawności i wynikających $\mathrm{z}$ niej konsekwencji. Wprowadzenie takiego zróżnicowania w zakresie ujawnianych reakcji uznano za niezbędne z punktu widzenia metodologicznego i wymogu trafnego ujmowania zjawisk w proponowanym sposobie ich pomiaru.

Przeprowadzona analiza czynnikowa dostarczyła wsparcia dla wielowymiarowej struktury RIDI, dając podstawy do wyodrębnienia 7 czynników wyjaśniających łącznie $44 \%$ wariancji wyników. Ustalone czynniki oddawały istotę poszczególnych podskal: Akceptacji/Uznania, Przystosowania,

${ }^{16}$ H. Livneh, R.F. Antonak, Reactions to disability, s. 16. 
Depresji, Uwewnętrznionego gniewu, Uzewnętrznionej wrogości i Zaprzeczania, mimo że empiryczne przypisanie itemów niezupełnie pokrywało się z przydzieleniem teoretycznym. Nie stwierdzono silnych związków korelacyjnych między podskalami a takimi zmiennymi, jak: płeć, wiek, poziom wykształcenia. Połączone podskale Uzewnętrznionej wrogości i Uwewnętrznionego gniewu różnicowały badanych pogrupowanych ze względu na wiek nabycia niepełnosprawności. Ustalono także pozytywną korelację między wynikami na skali Akceptacji Niepełnosprawności Linkowskiego i połączonymi podskalami Akceptacji/Uznania i Przystosowania wśród badanych doświadczających niepełnosprawności od przynajmniej 3 lat $(r=0,68)$. Wskaźniki rzetelności narzędzia okazały się zadowalające: współczynnik Cronbacha dla całej skali - 0,78, dla poszczególnych podskal: Sz - 0,79, N - 0,83, Z - 0,64, D 0,88, UG - 0,81, Uw - 0, 84, Uznanie - 0,78, Przystosowanie - 0,89. Pomimo że wykazano satysfakcjonujący poziom wewnętrznej zgodności kwestionariusza (wysokie międzyitemowe korelacje w podskalach), to dostrzeżono pewne ograniczenia $\mathrm{w}$ postaci niedostatecznie ustalonej swoistości poszczególnych podskal, co wymagało dalszego sprawdzenia empirycznego. Wyjaśnienia wymagała ścisła zbieżność podskal: Akceptacja/Uznanie - Przystosowanie, Depresja - Uwewnętrzniony gniew, Uzewnętrzniona wrogość - Niepokój. Założyli, iż pewien zaobserwowany stopień nakładania się reakcji typu depresyjnego i uwewnętrznionego gniewu oraz akceptacji i przystosowania kształtowany jest przede wszystkim przez ich współwystępowanie w czasie, podobieństwo objawów klinicznych pojawiających się w trakcie adaptacji do następstw niepełnosprawności oraz szeroki zakres badanych przejawów niepełnosprawności. Trafność zewnętrzna narzędzia została sprawdzona poprzez skorelowanie z wynikami otrzymanymi z użyciem Skali Akceptacji Niepełnosprawności Linkowskiego ${ }^{17}$.

Podsumowując, procedury analityczne zastosowane w pierwszym etapie sprawdzania właściwości psychometrycznych RIDI nie dały podstaw do wiernego odtworzenia hipotetycznie zakładanej struktury reagowania przystosowawczego u osób $\mathrm{z}$ niepełnosprawnością czy chorobą przewlekłą. Przyczyn takiej sytuacji upatrywano w znaczącej różnorodności próby badanych, która obejmowała osoby z niepełnosprawnością zarówno wrodzoną, traumatycznie nabytą, jak i wynikającą z chorób degeneracyjnych występujących w późniejszym okresie życia.

$\mathrm{W}$ celu zniwelowania ograniczeń zidentyfikowanych $\mathrm{w}$ pierwszym okresie prac nad narzędziem podjęto kolejne badania zorientowane na uzyskanie solidniejszych właściwości psychometrycznych, w tym ustalenie bar-

17 Tamże, s. 17-19. 
dziej przejrzystej struktury wewnętrznej ${ }^{18}$. Zredukowano listę itemów do 60 pozycji, które przetestowano na próbie bardziej homogenicznej niż poprzednio i składającej się ze 118 osób z powypadkowo nabytą fizyczną niepełnosprawnością. Utrzymano ustalone wcześniej kategorie reakcji przystosowawczych. Rezultaty analizy rzetelności (wartości współczynników Cronbacha: Sz - 0,75; N - 0,73; Z - 0,69; D - 0,78; UG - 0,74; UW - 0,79; A 0,77; P - 0,85) dowiodły homogeniczności wewnętrznej, jak i specyficzności $\mathrm{w}$ pomiarze poszczególnych reakcji. Analiza regresji pokazała ponadto, iż chroniczność była najlepszym predyktorem dla każdej z pięciu nieadaptacyjnych reakcji. Analiza czynnikowa dostarczyła podstaw do jednoznacznej interpretacji 5 czynników wyjaśniających $49 \%$ wariancji wyników, pozostałe itemy zostały rozproszone dając nieco mniej spójną charakterystykę reakcji szoku, depresji i uwewnętrznionego gniewu. Całkowicie wyodrębniona została reakcja zaprzeczania w kategorii niezależnej, swoistej, której we wcześniejszym etapie analiz przypisywano raczej funkcję pośredniczenia między reakcjami typowo nieprzystosowawczymi i wyraźnie adaptacyjnymi. Dokonane analizy pokazały także, że doświadczenie reakcji konstruktywnych/pozytywnych nie występuje $\mathrm{w}$ żadnej nieodzownie wymaganej kolejności, po uprzednio przyjmowanych negatywnych sposobach reagowania, np. zaprzeczania, depresji, uwewnętrznionego gniewu itp. Reakcje o charakterze pozytywnym i nieprzystosowawczym okazały się niezależne ${ }^{19}$.

Strukturę zakładanych psychospołecznych reakcji mierzonych skonstruowanym kwestionariuszem poddano dokładniejszemu testowaniu w późniejszych badaniach empirycznych. Przeanalizowano m.in. trzy wyodrębnione jej postaci: a) adaptacja jako pojedynczy czynnik, jeden globalny wymiar, w którym pozytywne i negatywne reakcje stanowią dwa przeciwległe bieguny; b) adaptacja obejmująca dwa oddzielne i nieskorelowane wymiary (przystosowawczy i nieadaptacyjny); c) adaptacja wyrażająca się w określonych relacjach między zaprzeczaniem a pozytywną i negatywną afektywnością (mierzoną m.in. poziomem jakości życia i satysfakcji z ży(ia) ${ }^{20}$. W wyniku przeprowadzonego dopasowania każdego ze stworzonych modeli adaptacji do danych empirycznych, za najbardziej satysfakcjonujący uznano drugi z nich. Dwuczynnikowa struktura adaptacji obejmuje dwa wymiary reakcji: natury przystosowawczej (akceptacje i przystosowanie) i nieprzystosowawczej (szok, niepokój, depresję, uwewnętrzniony gniew,

18 H. Livneh, R.F. Antonak, Temporal structure of adaptation to disability, Rehabilitation Counseling Bulletin, 1991, 34(2), s. 300.

19 Tamże, s. 309.

${ }^{20} \mathrm{H}$. Livneh, E. Martz, T. Bodner, Psychosocial adaptation to chronic illness and disability: A preliminary study, s. 258. 
uzewnętrznioną wrogość). Wyodrębniono ponadto dodatkowy wymiar adaptacji - zaprzeczanie (trwałości fizycznego uszkodzenia i apercepcję zagrażających informacji) $\mathrm{w}$ dwóch postaciach: 1) zaprzeczanie wyrażające się w myśleniu życzeniowym, targowaniu się z Bogiem w celu usunięcia posiadanych ograniczeń; 2) zaprzeczanie odzwierciedlające się w głębokim przekonaniu o możliwości cudownego uzdrowienia. Uzyskane dane empiryczne wskazały na złożoną oraz hierarchiczną naturę przystosowania i składających się na niego reakcji, możliwą do zobrazowania na kontinuum obejmującym dwa lub trzy wymiary (negatywne przystosowanie - zaprzeczanie pozytywne przystosowanie). Struktura ta została w wysokim stopniu potwierdzona $w$ innych badaniach ${ }^{21}$, także $w$ greckiej adaptacji narzędzia ${ }^{22}$.

\section{Zastosowanie oryginalnej wersji kwestionariusza}

Oryginalna wersja kwestionariusza wykorzystywana jest zarówno do analizy samego zjawiska przystosowania, jak i poszczególnych sposobów reagowania. Rozpatrywane są także wiązki reakcji przystosowawczych, określane jako np. pozytywna/negatywna adaptacja. Można wyodrębnić kilka grup analiz prowadzonych z zastosowaniem tego kwestionariusza:

1. Dociekanie struktury samego zjawiska psychospołecznej adaptacji23; testowanie powiązania między radzeniem i adaptacją ${ }^{24}$.

2. Poszukiwanie uwarunkowań samego zjawiska psychospołecznej adaptacji u osób z niepełnosprawnością i chorobą przewlekłą (u osób z urazem rdzenia ${ }^{25}$, po amputacji 26 , u studentów z różnymi typami niepełnosprawności ${ }^{27}$, u osób po udarze mózgu ${ }^{28}$ oraz z niepełnosprawnością fizyczną ${ }^{29}$ ).

${ }^{21}$ H. Livneh, S.M. Lott, R.F. Antonak, Patterns of psychosocial adaptation to chronic illness and disability: a cluster analytic approach, Psychology Health and Medicine, 2004, 9(4), s. 412-421; E. Martz, R. Roessler, H. Livneh, Responses to insulin reactions and long-term adaptation to diabetes, Journal of Rehabilitation, 2002, 68(2), s. 18.

22 Por. E. Psarra, G. Kleftaras, Adaptation to physical disabilities: The role of meaning in life and depression, The European Journal of Counseling Psychology, 2013, 2(1), s. 83.

${ }^{23}$ H. Livneh, E. Martz, T. Bodner, Psychosocial adaptation to chronic illness and disability: A preliminary study, s. 251-261; H. Livneh, S.M. Lott, R.F. Antonak, Patterns of psychosocial adaptation to chronic illness, s. 411-430.

${ }^{24} \mathrm{H}$. Livneh, L.M. Wilson, Coping strategies as predictors and mediators of disability-related variables and psychosocial adaptation, Rehabilitation Counseling Bulletin, 2003, 46(1), s. 194-208.

${ }^{25}$ E. Martz, Do post-traumatic stress symptoms predict reactions of adaptation to disability after a sudden-onset spinal cord injury? International Journal of Rehabilitation Research, 2004a, 27(3), s. 185-194; H. Livneh, E. Martz, Associations and predictors of posttraumatic stress-levels according to person-related, disability-related and trauma-related variables among individuals with spinal cord injuries, Rehabilitation Psychology, 2005, 50(2), s. 577-586; E. Martz i in., Predictors of psychoso- 
3. Analiza wybranych reakcji przystosowawczych jako wskaźników przebiegu procesu adaptacji (reagowanie we wczesnych i późniejszych etapach rozwoju choroby ${ }^{30}$, badanie zmienności reakcji w wybranych odcinkach czasowych u studentów z niepełnosprawnością ${ }^{31}$, właściwości choroby a dynamika adaptacji u osób z cukrzycą ${ }^{32}$, psychospołeczne reakcje jako predyktory wtórnych komplikacji zdrowotnych u osób po urazie rdzenia kręgowego ${ }^{33}$.

4. Analiza wiązek reakcji przystosowawczych określanych jako pozytywna/negatywna adaptacja - np. ujmowanie akceptacji niepełnosprawności na podstawie połączenia akceptacji poznawczej i emocjonalnobehawioralnej ${ }^{34}$.

5. Powiązania reakcji przystosowawczych z innymi zmiennymi psychospołecznego funkcjonowania jednostek $\mathrm{z}$ ograniczeniami $\mathrm{w}$ zdrowiu i sprawności (analiza w kategorii predyktorów zatrudnienia studentów college'ów z niepełnosprawnościąis, powiązanie z orientacją przyszłościową u osób z urazem rdzenia ${ }^{36}$, związek z psychologicznym dobrostanem u osób

cial adaptation among people with spinal cord injury or disorder, Archives of Physical Medicine and Rehabilitation, 2005, 86(6), s. 1182-1192.

${ }^{26}$ H. Livneh, R.F. Antonak, J. Gerhardt, Psychosocial adaptation to amputation: the role of sociodemographic variables, disability related factors and coping strategies, International Journal of Rehabilitation Research, 1999, 22(1), s. 21-31.

${ }^{27}$ H. Livneh, E. Martz, L.M. Wilson, Denial and perceived visibility as predictors of adaptation to disability among college students, Journal of Vocational Rehabilitation, 2001, 16(2), s. 227-234.

${ }_{28} \mathrm{M}$. Schönberger $\mathrm{i}$ in. Development and predictors of psychological adjustment during the course of community-based rehabilitation of traumatic brain injury: A preliminary study, Neuropsychological Rehabilitation: An International Journal, 2014, 24(2), s. 202-219.

${ }_{29}$ E. Psarra, G. Kleftaras, Adaptation to physical disabilities: The role of meaning in life and depression, s. 79-99.

30 G.J. Treharne i in., Reactions to disability in patients with early versus established rheumatoid arthritis, Scandinavian Journal of Rheumatology 2004, 33(1), s. 30-38.

${ }^{31} \mathrm{E}$. Martz, A one - year follow-up study on psychosocial adaptation of college students with disabilities, Journal of Vocational Rehabilitation, 2004b, 21(1), s. 1-7.

32 E. Martz, R. Roessler, H. Livneh, Responses to insulin reactions and long-term adaptation to diabetes, Journal of Rehabilitation, 2002, 68(2), s. 14-21.

${ }^{33}$ E. Martz i in., Psychosocial responses to spinal cord injury as predictors of pressure scores, International Journal of Clinical and Health Psychology, 2010, 10(2), s. 203-223.

${ }^{34}$ M.in. E. Martz, H. Livneh, J. Turpin, Locus of control orientation and acceptance of disability, Journal of Applied Rehabilitation Counseling, 2000, 31(3), s. 14-21.

35 E. Martz, Invisibility of disability and work experience as predictors of employment among community college students with disabilities, Journal of Vocational Rehabilitation, 2003, 18(3), s. $153-161$.

36 E. Martz, Do Reactions of Adaptation to Disability Influence the Fluctuation of Future Time Orientation Among Individuals with Spinal Cord Injuries? Rehabilitation Counseling Bulletin, 2004c, 47(2), s. 86-95. 
z uszkodzonym słuchem ${ }^{37}$, relacje zasobów osobistych i psychospołecznej adaptacji u osób z urazem rdzenia ${ }^{38}$, powiązanie symptomatologii depresyjnej i poczucia sensu życia z reakcjami przystosowawczymi ${ }^{39}$, korelacja dysfunkcjonalnego myślenia o karierze i przystosowania do życia z niepełnosprawnością u studentów z trudnościami w uczeniu sięe${ }^{40}$ ).

\section{Opracowanie polskiej wersji językowej}

Prace walidacyjne rozpoczęto od przekładu kwestionariusza, który obejmował translację i retranslację. Reactions to Impairment and Disability Inventory (RIDI) po uzyskaniu zgody autorów zostało przetłumaczone przez trzech niezależnych tłumaczy na język polski. Wszystkie przetłumaczone itemy przedyskutowano i przyjęto ich uzgodnioną wersję najlepiej oddającą istotę zawartych w nich wyrażeń. Następnie zostały one poddane tłumaczeniu zwrotnemu (retranslacji) przez kolejnych trzech tłumaczy, którzy oprócz znajomości języka angielskiego posiadali również wykształcenie pedagogiczne ( 2 osoby) i psychologiczne (1 osoba), na podstawie przydzielonego im jednego z trzech tłumaczeń. Wątpliwości wzbudzały terminy: "anxiety” i „denial”, które ostatecznie zostały przyjęte jako „niepokój” i „zaprzeczanie". Otrzymana po dwukrotnym tłumaczeniu wersja kwestionariusza została przeanalizowana przez sędziów kompetentnych (4 pedagogów specjalnych i 3 psychologów rehabilitacji), którzy wprowadzili nieznaczne modyfikacje $w$ kilku itemach. Skorygowana na podstawie ich sugestii treść itemów nadal była zgodna z tłumaczeniem, niemniej lepiej oddawała naturę określanych w nich reakcji.

Uzgodnioną eksperymentalną wersję narzędzia, która została opatrzona nazwą Kwestionariusz Reakcji Przystosowawczych (KRK) bezpośrednio wskazującą na przedmiot pomiaru, wykorzystano w badaniach walidacyjnych.

${ }_{37}$ J.M. Meyer, S. Kashubeck-West, Well-being of individuals with late-deafness, Rehabilitation Psychology, 2013, 58(2), s. 124-136.

$38 \mathrm{H}$. Livneh, E. Martz, Coping strategies and resources as predictors of psychosocial adaptation, s. 329-339; D.C. Lustig, The adjustment process for individuals with spinal cord injury: The impact of perceived pre-morbid sense of coherence, Rehabilitation Counseling Bulletin, 2005, 48(1), s. 146-156.

${ }^{39}$ E. Psarra, G. Kleftaras, Adaptation to physical disabilities: The role of meaning in life, s. 79-99.

40 A. Dipeolu $i$ in., The relationship between dysfunctional career thoughts and adjustment to disability in college students with learning disabilities, Journal of Career Assessment, 2002, 10(4), s. 413-427. 


\section{Właściwości psychometryczne polskiej wersji kwestionariusza}

Ustalenie psychometrycznych właściwości polskiej wersji kwestionariusza RIDI obejmowało następujące etapy: a) analizę struktury wewnętrznej; b) oszacowanie rzetelności i stabilności narzędzia; c) ustalanie trafności kwestionariusza: teoretycznej, zbieżnej i kryterialnej.

\section{Osoby badane}

Weryfikacja charakterystyki psychometrycznej narzędzia została przeprowadzona na grupie 940 osób (409 kobiet i 531 mężczyzn). Średnia wieku badanych wyniosła 44,8 lat. W przeważającej części badani pochodzili ze wsi (58,40\%, pozostali to mieszkańcy miasta $-41,60 \%)$. Stan cywilny badanych przedstawiał się następująco: $27,45 \%$ - osoby samotne; $39,79 \%$ - pozostający w związku małżeńskim; 19,25\% - rozwiedzeni lub w separacji; 13,51\% osoby owdowiałe. Struktura wykształcenia badanych: wyższe $(9,91 \%)$, niepełne wyższe $(16,74 \%)$, średnie $(33,51 \%)$, zawodowe $(31,70 \%)$, podstawowe $(7,17 \%)$. Dane dotyczące rodzaju niepełnosprawności przedstawia tabela 1.

Tabela 1

Rodzaj niepełnosprawności badanych

\begin{tabular}{|l|c|c|}
\hline \multicolumn{1}{|c|}{ Rodzaj niepełnosprawności } & $N$ & $\%$ \\
\hline Amputacja & 162 & 17,23 \\
\hline Uraz rdzenia kręgowego & 155 & 16,49 \\
\hline Stwardnienie rozsiane & 144 & 15,32 \\
\hline Cukrzyca & 154 & 16,38 \\
\hline Nowotwór & 133 & 14,15 \\
\hline Choroby układu krążenia & 118 & 12,55 \\
\hline $\begin{array}{l}\text { Reumatoidalne zapalenie } \\
\text { stawów }\end{array}$ & 74 & 7,87 \\
\hline Razem & 940 & 100 \\
\hline
\end{tabular}

\section{Struktura wewnętrzna kwestionariusza}

Pozycje kwestionariusza poddano eksploracyjnej analizie czynnikowej metodą głównych składowych ortogonalną z rotacją Varimax. Zasadność wyboru modelu analizy czynnikowej została potwierdzona formalnie wskaźnikiem KMO $(0,94)$ oraz testem sferyczności Bartletta $\left(\mathrm{chi}^{2}=18\right.$, 57; 
$p<0,001)$. Biorąc pod uwagę kryterium Kaisera oraz wykres osypiska, mając również na uwadze oryginalną wersję kwestionariusza, wyodrębniono 8 czynników, które łącznie wyjaśniają 62,13\% wariancji danych (tab. 2 i 3).

Tabela 2

Wartości własne i procent wyjaśnianej wariancji wyodrębnionych czynników

\begin{tabular}{|c|c|c|c|}
\hline Czynnik & Ogółem & \% Wariancji & \% Skumulowany \\
\hline 1 & 14,45 & 24,08 & 24,08 \\
\hline 2 & 5,49 & 9,16 & 33,24 \\
\hline 3 & 4,38 & 7,30 & 40,54 \\
\hline 4 & 3,54 & 5,90 & 46,44 \\
\hline 5 & 2,64 & 4,41 & 50,85 \\
\hline 6 & 2,42 & 4,03 & 54,88 \\
\hline 7 & 2,24 & 3,74 & 58,62 \\
\hline 8 & 2,11 & 3,51 & 62,14 \\
\hline
\end{tabular}

Tabela 3

Wyniki eksploracyjnej analizy czynnikowej przeprowadzonej dla KRP

\begin{tabular}{|c|c|c|c|c|c|c|c|c|}
\hline $\begin{array}{c}\text { Nu- } \\
\text { mer } \\
\text { pozy- } \\
\text { cji }\end{array}$ & $\begin{array}{c}\text { Czyn- } \\
\text { nik } \\
\text { I }\end{array}$ & $\begin{array}{c}\text { Czyn- } \\
\text { nik } \\
\text { II }\end{array}$ & $\begin{array}{c}\text { Czyn- } \\
\text { nik } \\
\text { III }\end{array}$ & $\begin{array}{c}\text { Czyn- } \\
\text { nik } \\
\text { IV }\end{array}$ & $\begin{array}{c}\text { Czyn- } \\
\text { nik } \\
\text { V }\end{array}$ & $\begin{array}{c}\text { Czyn- } \\
\text { nik } \\
\text { VI }\end{array}$ & $\begin{array}{c}\text { Czyn- } \\
\text { nik } \\
\text { VII }\end{array}$ & $\begin{array}{c}\text { Czyn- } \\
\text { nik } \\
\text { VIII }\end{array}$ \\
\hline $\mathbf{1}$ & 0,27 & 0,06 & $-0,01$ & 0,11 & $-0,03$ & 0,23 & $\mathbf{0 , 5 6}$ & 0,10 \\
\hline $\mathbf{2}$ & 0,08 & 0,07 & $\mathbf{0 , 6 0}$ & $-0,04$ & 0,14 & 0,04 & 0,09 & 0,15 \\
\hline $\mathbf{3}$ & 0,21 & $-0,04$ & 0,14 & 0,12 & 0,12 & 0,13 & $\mathbf{0 , 4 5}$ & 0,11 \\
\hline $\mathbf{4}$ & $\mathbf{0 , 6 6}$ & 0,08 & 0,11 & 0,15 & $-0,05$ & 0,16 & 0,08 & 0,04 \\
\hline $\mathbf{5}$ & 0,03 & 0,00 & $\mathbf{0 , 7 6}$ & $-0,05$ & 0,12 & 0,05 & 0,11 & 0,10 \\
\hline $\mathbf{6}$ & 0,31 & $-0,20$ & 0,10 & 0,18 & 0,08 & 0,24 & $\mathbf{0 , 5 3}$ & 0,00 \\
\hline $\mathbf{7}$ & $-0,03$ & $\mathbf{0 , 6 6}$ & 0,07 & $-0,04$ & 0,11 & $-0,13$ & $-0,09$ & 0,13 \\
\hline $\mathbf{8}$ & 0,32 & $-0,04$ & 0,16 & 0,07 & $-0,14$ & $\mathbf{0 , 4 5}$ & 0,30 & $-0,10$ \\
\hline $\mathbf{9}$ & $\mathbf{0 , 4 8}$ & 0,04 & 0,05 & 0,06 & $-0,13$ & 0,37 & 0,23 & $-0,10$ \\
\hline $\mathbf{1 0}$ & $\mathbf{0 , 6 2}$ & 0,06 & $-0,12$ & 0,02 & $-0,11$ & 0,36 & 0,21 & 0,01 \\
\hline $\mathbf{1 1}$ & 0,27 & $\mathbf{0 , 4 5}$ & $-0,05$ & $-0,09$ & 0,00 & 0,22 & $-0,26$ & 0,09 \\
\hline $\mathbf{1 2}$ & 0,18 & $-0,24$ & 0,11 & 0,19 & 0,03 & 0,30 & $\mathbf{0 , 4 7}$ & $-0,15$ \\
\hline $\mathbf{1 3}$ & $-0,02$ & $-0,00$ & $\mathbf{0 , 6 9}$ & $-0,03$ & 0,03 & 0,15 & 0,07 & 0,06 \\
\hline $\mathbf{1 4}$ & 0,25 & 0,04 & 0,10 & $-0,03$ & $\mathbf{0 , 4 9}$ & 0,21 & $-0,07$ & $-0,13$ \\
\hline $\mathbf{1 5}$ & 0,16 & $\mathbf{0 , 6 2}$ & 0,02 & $-0,02$ & 0,23 & $-0,15$ & 0,01 & $-0,12$ \\
\hline $\mathbf{1 6}$ & 0,28 & $-0,24$ & $-0,01$ & 0,15 & $-0,09$ & 0,33 & $\mathbf{0 , 4 0}$ & $-0,05$ \\
\hline $\mathbf{1 7}$ & 0,16 & $-0,11$ & 0,18 & 0,15 & 0,06 & $\mathbf{0 , 5 7}$ & 0,31 & $-0,06$ \\
\hline $\mathbf{1 8}$ & 0,17 & 0,06 & $-0,00$ & $\mathbf{0 , 5 9}$ & $-0,03$ & 0,07 & 0,08 & $-0,12$ \\
\hline $\mathbf{1 9}$ & 0,23 & 0,22 & 0,09 & $-0,08$ & $\mathbf{0 , 4 7}$ & 0,19 & 0,09 & $-0,17$ \\
\hline $\mathbf{2 0}$ & 0,35 & $-0,09$ & $-0,01$ & 0,12 & 0,19 & 0,22 & $-0,06$ & $\mathbf{0 , 4 2}$ \\
\hline $\mathbf{2 1}$ & 0,23 & 0,08 & 0,13 & 0,13 & $-0,06$ & $\mathbf{0 , 6 1}$ & 0,09 & 0,08 \\
\hline $\mathbf{2 2}$ & 0,03 & 0,10 & $\mathbf{0 , 7 8}$ & $-0,04$ & 0,01 & 0,06 & 0,12 & $-0,03$ \\
\hline & & & & & & & & \\
\hline
\end{tabular}




\begin{tabular}{|c|c|c|c|c|c|c|c|c|}
\hline $\begin{array}{c}\text { Nu- } \\
\text { mer } \\
\text { pozy- } \\
\text { cji }\end{array}$ & $\begin{array}{c}\text { Czyn- } \\
\text { nik } \\
\text { I }\end{array}$ & $\begin{array}{c}\text { Czyn- } \\
\text { nik } \\
\text { II }\end{array}$ & $\begin{array}{c}\text { Czyn- } \\
\text { nik } \\
\text { III }\end{array}$ & $\begin{array}{c}\text { Czyn- } \\
\text { nik } \\
\text { IV }\end{array}$ & $\begin{array}{c}\text { Czyn- } \\
\text { nik } \\
\text { V }\end{array}$ & $\begin{array}{c}\text { Czyn- } \\
\text { nik } \\
\text { VI }\end{array}$ & $\begin{array}{c}\text { Czyn- } \\
\text { nik } \\
\text { VII }\end{array}$ & $\begin{array}{c}\text { Czyn- } \\
\text { nik } \\
\text { VIII }\end{array}$ \\
\hline 23 & 0,57 & 0,07 & $-0,09$ & 0,13 & 0,03 & 0,30 & $-0,08$ & $-0,19$ \\
\hline 24 & 0,22 & $-0,08$ & 0,09 & 0,26 & 0,01 & 0,58 & 0,15 & $-0,09$ \\
\hline 25 & 0,21 & 0,03 & $-0,12$ & 0,64 & 0,10 & 0,07 & $-0,00$ & $-0,22$ \\
\hline 26 & 0,32 & $-0,04$ & $-0,02$ & 0,53 & $-0,04$ & 0,25 & 0,10 & $-0,24$ \\
\hline 27 & 0,01 & 0,62 & 0,05 & 0,06 & 0,20 & $-0,13$ & 0,10 & 0,17 \\
\hline 28 & 0,11 & $-0,20$ & 0,03 & 0,15 & 0,07 & 0,21 & 0,03 & 0,45 \\
\hline 29 & 0,28 & $-0,24$ & $-0,03$ & 0,19 & 0,27 & 0,00 & 0,41 & 0,07 \\
\hline 30 & $-0,12$ & 0,56 & 0,01 & $-0,05$ & 0,24 & 0,17 & 0,36 & 0,00 \\
\hline 31 & 0,19 & 0,02 & 0,22 & 0,03 & $-0,09$ & 0,48 & 0,12 & $-0,28$ \\
\hline 32 & 0,58 & 0,03 & $-0,02$ & 0,14 & $-0,09$ & 0,20 & 0,04 & 0,26 \\
\hline 33 & 0,72 & 0,04 & 0,04 & 0,15 & 0,12 & 0,05 & 0,23 & $-0,00$ \\
\hline 34 & 0,24 & $-0,25$ & 0,05 & 0,16 & 0,08 & 0,33 & $-0,07$ & 0,53 \\
\hline 35 & 0,04 & 0,13 & 0,12 & $-0,07$ & 0,71 & 0,18 & 0,10 & 0,18 \\
\hline 36 & 0,01 & 0,18 & 0,06 & $-0,00$ & 0,68 & $-0,10$ & 0,17 & $-0,04$ \\
\hline 37 & 0,29 & $-0,21$ & $-0,06$ & 0,08 & 0,20 & 0,16 & 0,47 & 0,16 \\
\hline 38 & 0,31 & $-0,18$ & 0,18 & 0,11 & 0,11 & 0,33 & 0,08 & 0,40 \\
\hline 39 & 0,69 & $-0,01$ & 0,11 & 0,16 & 0,00 & 0,07 & 0,32 & 0,18 \\
\hline 40 & 0,16 & 0,27 & 0,11 & 0,13 & 0,54 & $-0,11$ & 0,15 & 0,14 \\
\hline 41 & 0,10 & 0,00 & 0,69 & $-0,00$ & 0,08 & 0,09 & 0,09 & $-0,02$ \\
\hline 42 & 0,27 & $-0,01$ & 0,14 & 0,15 & 0,05 & 0,53 & $-0,11$ & 0,12 \\
\hline 43 & 0,26 & $-0,15$ & 0,31 & 0,21 & 0,13 & 0,22 & $-0,09$ & 0,41 \\
\hline 44 & 0,23 & $-0,08$ & 0,22 & 0,15 & $-0,01$ & 0,52 & $-0,12$ & 0,01 \\
\hline 45 & 0,10 & 0,05 & $-0,01$ & 0,69 & $-0,04$ & 0,22 & $-0,24$ & 0,17 \\
\hline 46 & 0,05 & 0,60 & 0,05 & 0,07 & 0,28 & 0,36 & $-0,03$ & 0,03 \\
\hline 47 & 0,28 & $-0,08$ & 0,14 & 0,55 & $-0,02$ & 0,15 & 0,05 & $-0,04$ \\
\hline 48 & 0,39 & $-0,15$ & 0,06 & 0,56 & $-0,01$ & $-0,03$ & $-0,02$ & 0,08 \\
\hline 49 & 0,23 & $-0,16$ & $-0,01$ & 0,27 & 0,21 & 0,13 & 0,03 & 0,40 \\
\hline 50 & $-0,09$ & 0,10 & 0,59 & 0,09 & 0,08 & 0,16 & $-0,00$ & $-0,07$ \\
\hline 51 & $-0,13$ & 0,18 & 0,12 & 0,04 & 0,67 & 0,30 & 0,09 & 0,07 \\
\hline 52 & 0,07 & $-0,03$ & 0,65 & 0,10 & 0,08 & 0,00 & 0,17 & $-0,03$ \\
\hline 53 & 0,13 & 0,06 & $-0,07$ & 0,32 & $-0,08$ & $-0,08$ & 0,40 & 0,24 \\
\hline 54 & $-0,02$ & 0,00 & $-0,05$ & 0,46 & 0,10 & $-0,03$ & 0,15 & 0,27 \\
\hline 55 & $-0,06$ & 0,63 & 0,04 & 0,03 & 0,13 & 0,33 & 0,05 & 0,22 \\
\hline 56 & 0,26 & $-0,11$ & 0,06 & 0,18 & 0,10 & 0,29 & 0,09 & 0,40 \\
\hline 57 & 0,05 & 0,07 & $-0,03$ & 0,59 & $-0,04$ & $-0,05$ & $-0,02$ & 0,14 \\
\hline 58 & $-0,14$ & 0,32 & 0,13 & $-0,00$ & 0,54 & 0,24 & $-0,05$ & 0,07 \\
\hline 59 & 0,20 & $-0,25$ & 0,10 & 0,27 & 0,26 & 0,16 & 0,06 & 0,42 \\
\hline 60 & $-0,22$ & 0,50 & 0,11 & 0,06 & 0,12 & 0,03 & 0,11 & $-0,10$ \\
\hline
\end{tabular}

Opierając się na nazewnictwie poszczególnych podskal $\mathrm{w}$ oryginalnej wersji kwestionariusza, uzyskane czynniki określono następująco: Czynnik I 
- Uwewnętrzniony gniew; Czynnik II - Przystosowanie; Czynnik 3 - Zaprzeczanie; Czynnik IV - Uzewnętrzniona wrogość; Czynnik V - Akceptacja; Czynnik VI - Niepokój; Czynnik VII - Depresja; Czynnik VIII - Szok ${ }^{41}$. Niższe (niż zakładano) ładunki czynnikowe w podskalach: Depresji i Szoku wskazują na nieco słabszą ich spójność wewnętrzną w porównaniu z pozostałymi podskalami. Należy ponadto zaznaczyć, iż wystąpiły nieznaczne różnice między wersją oryginalną i polską kwestionariusza w zakresie przypisania itemów do poszczególnych czynników. Na przykład, item 20: „Wydaje mi się, że nic już nie będzie takie same" został włączony do czynnika VIII, wyrażającego reakcję szoku, podczas gdy w oryginalnej wersji kwestionariusza item ten wchodzi w skład podskali Depresji. Item 53: „Od kiedy jestem niepełnosprawna/y, śnią mi się koszmary" w RIDI znajdujący się w podskali Niepokoju, w KKR służy do zdiagnozowania reakcji depresji. Item 26: „Wpadam w taki szał, że mogłabym/mógłbym rozbijać przedmioty" został zaliczony w polskiej wersji do podskali Uzewnętrzniona wrogość, pierwotnie włączany do Uwewnętrznionego gniewu.

\section{Statystyki opisowe podskal kwestionariusza}

W tabeli 4 zawarte są statystyki opisowe dla wszystkich wyodrębnionych podskal obliczone dla całej grupy badanych, ustalono je również dla poszczególnych podgrup (tab. 5).

Tabela 4

Statystyki opisowe dla podskal KRP (cała próba badanych: $\mathrm{N}$ = 940)

\begin{tabular}{|c|c|c|c|c|c|c|c|c|c|}
\hline Podskala & $\begin{array}{c}\text { Liczba } \\
\text { ite- } \\
\text { mów }\end{array}$ & Min. & Max. & $\mathrm{M}$ & $\mathrm{SD}$ & $\begin{array}{c}\text { Media- } \\
\text { na }\end{array}$ & $\begin{array}{c}\text { Sko- } \\
\text { śność }\end{array}$ & $\begin{array}{c}\text { Kurto- } \\
\text { za }\end{array}$ & $\begin{array}{c}\text { Warian- } \\
\text { cja }\end{array}$ \\
\hline Sz & 8 & 8 & 32 & 16,93 & 5,30 & 17 & 0,34 & $-0,44$ & 28,0 \\
\hline N & 7 & 7 & 29 & 12,82 & 4,39 & 12 & 0,56 & $-0,41$ & 19,25 \\
\hline Z & 7 & 7 & 31 & 13,60 & 5,16 & 13 & 0,57 & $-0,47$ & 26,64 \\
\hline D & 8 & 8 & 32 & 15,92 & 5,03 & 16 & 0,52 & $-0,17$ & 25,34 \\
\hline UG & 7 & 7 & 30 & 15,03 & 5,07 & 15 & 0,39 & $-0,41$ & 25,75 \\
\hline UW & 8 & 8 & 32 & 17,17 & 4,75 & 17 & 0,31 & $-0,52$ & 22,58 \\
\hline A & 7 & 7 & 28 & 17,86 & 4,50 & 18 & $-0,11$ & $-0,60$ & 20,23 \\
\hline P & 8 & 8 & 32 & 22,11 & 5,30 & 22 & $-0,32$ & $-0,21$ & 28,13 \\
\hline
\end{tabular}

${ }^{41}$ Zob. Por. S. Byra, H. Livneha i R. Antonaka koncepcja, s. 11. 
Tabela 5

Statystyki opisowe dla podskal KRP (poszczególne grupy badanych)

\begin{tabular}{|c|c|c|c|c|c|c|c|c|c|}
\hline Podskala & $N$ & Min. & Max. & M & SD & Mediana & Wariancja & Skośność & Kurtoza \\
\hline \multicolumn{9}{|c|}{ Amputacja } & \\
\hline $\mathrm{Sz}$ & 142 & 8 & 29 & 16,91 & 6,24 & 16 & 38,92 & 0,26 & $-1,05$ \\
\hline $\mathrm{N}$ & 142 & 7 & 24 & 13,44 & 4,81 & 12 & 23,13 & 0,45 & $-0,27$ \\
\hline$Z$ & 142 & 7 & 23 & 11,11 & 4,13 & 10 & 17,05 & 0,23 & 0,04 \\
\hline $\mathrm{D}$ & 142 & 8 & 29 & 16,94 & 5,30 & 17 & 28,10 & 0,24 & $-0,74$ \\
\hline UG & 142 & 7 & 28 & 17,35 & 4,99 & 17,50 & 24,88 & 0,26 & $-0,16$ \\
\hline UW & 142 & 9 & 29 & 17,34 & 4,83 & 16 & 23,34 & 0,18 & $-0,60$ \\
\hline $\mathrm{A}$ & 142 & 8 & 28 & 16,84 & 4,82 & 16 & 23,26 & 0,31 & $-0,89$ \\
\hline $\mathrm{P}$ & 142 & 12 & 32 & 23,04 & 3,80 & 23 & 14,44 & 0,17 & 0,23 \\
\hline \multicolumn{10}{|c|}{ Uraz rdzenia kręgowego } \\
\hline $\mathrm{Sz}$ & 143 & 8 & 32 & 16,91 & 5,78 & 16 & 33,38 & 0,25 & 0,13 \\
\hline $\mathrm{N}$ & 149 & 7 & 27 & 11,25 & 4,04 & 10 & 16,36 & 1,14 & 1,22 \\
\hline $\mathrm{Z}$ & 150 & 7 & 28 & 11,92 & 4,26 & 11 & 18,14 & 1,35 & 2,01 \\
\hline $\mathrm{D}$ & 151 & 8 & 32 & 15,25 & 5,52 & 14 & 30,44 & 1,06 & 0,74 \\
\hline UG & 147 & 7 & 28 & 15,67 & 6,12 & 16 & 37,50 & 0,30 & $-1,04$ \\
\hline UW & 152 & 8 & 28 & 16,65 & 5,09 & 16 & 25,90 & 0,32 & $-0,79$ \\
\hline $\mathrm{A}$ & 152 & 8 & 25 & 17,32 & 4,57 & 17,50 & 20,89 & $-0,09$ & $-1,17$ \\
\hline $\mathrm{P}$ & 152 & 11 & 31 & 22,76 & 5,45 & 22,50 & 29,73 & $-0,42$ & $-0,49$ \\
\hline \multicolumn{10}{|c|}{ Stwardnienie rozsiane } \\
\hline $\mathrm{Sz}$ & 163 & 9 & 30 & 17,35 & 4,62 & 17 & 21,35 & 0,13 & $-0,50$ \\
\hline $\mathrm{N}$ & 160 & 7 & 24 & 13,64 & 4,51 & 13,50 & 20,37 & 0,23 & $-0,45$ \\
\hline $\mathrm{Z}$ & 164 & 7 & 31 & 14,80 & 5,08 & 15 & 25,83 & 0,34 & $-0,37$ \\
\hline $\mathrm{D}$ & 157 & 8 & 30 & 16,37 & 4,64 & 17 & 21,57 & $-0,07$ & $-0,40$ \\
\hline UG & 164 & 7 & 26 & 15,14 & 4,81 & 15 & 23,19 & 0,02 & $-0,48$ \\
\hline UW & 162 & 8 & 28 & 17,26 & 4,27 & 17 & 18,27 & 0,16 & $-0,11$ \\
\hline $\mathrm{A}$ & 164 & 7 & 28 & 17,72 & 3,99 & 17 & 15,94 & $-0,16$ & 0,11 \\
\hline $\mathrm{P}$ & 162 & 8 & 32 & 20,18 & 5,05 & 21 & 25,52 & $-0,29$ & 0,23 \\
\hline \multicolumn{10}{|c|}{ Cukrzyca } \\
\hline $\mathrm{Sz}$ & 154 & 8 & 30 & 16,64 & 4,76 & 16,50 & 22,69 & 0,22 & $-0,41$ \\
\hline $\mathrm{N}$ & 154 & 7 & 22 & 12,28 & 3,63 & 12 & 13,17 & 0,43 & $-0,42$ \\
\hline Z & 154 & 7 & 27 & 13,92 & 5,04 & 13,50 & 25,37 & 0,57 & $-0,31$ \\
\hline $\mathrm{D}$ & 154 & 8 & 27 & 15,56 & 4,62 & 15 & 21,33 & 0,53 & $-0,32$ \\
\hline UG & 154 & 7 & 26 & 12,60 & 4,10 & 11 & 16,80 & 1,07 & 0,26 \\
\hline UW & 154 & 9 & 32 & 16,95 & 4,39 & 17 & 19,30 & 0,47 & $-0,06$ \\
\hline $\mathrm{A}$ & 154 & 8, & 27 & 18,11 & 4,69 & 18 & 22,01 & $-0,20$ & $-0,56$ \\
\hline $\mathrm{P}$ & 154 & 9 & 32 & 21,12 & 5,14 & 22 & 26,41 & $-0,06$ & $-0,20$ \\
\hline \multicolumn{10}{|c|}{ Choroby nowotworowe } \\
\hline $\mathrm{Sz}$ & 132 & 8 & 31 & 17,44 & 5,53 & 17 & 30,64 & 0,27 & $-0,56$ \\
\hline $\mathrm{N}$ & 133 & 7 & 23 & 12,90 & 4,24 & 13 & 17,97 & 0,39 & $-0,78$ \\
\hline $\mathrm{Z}$ & 133 & 7 & 28 & 15,32 & 5,52 & 16 & 30,43 & 0,09 & $-1,06$ \\
\hline $\mathrm{D}$ & 133 & 8 & 32 & 15,41 & 5,15 & 14 & 26,56 & 0,75 & 0,14 \\
\hline
\end{tabular}




\begin{tabular}{|c|c|c|c|c|c|c|c|c|c|}
\hline Podskala & $N$ & Min. & Max. & M & SD & Mediana & Wariancja & Skośność & Kurtoza \\
\hline UG & 133 & 7 & 28 & 14,77 & 4,65 & 14 & 21,62 & 0,46 & $-0,16$ \\
\hline UW & 133 & 8 & 29 & 17,80 & 4,88 & 17 & 23,85 & 0,21 & $-0,47$ \\
\hline A & 132 & 7 & 28 & 18,95 & 4,47 & 20 & 19,96 & $-0,28$ & $-0,12$ \\
\hline P & 133 & 9 & 32 & 23,89 & 5,50 & 25 & 30,25 & $-0,55$ & $-0,33$ \\
\hline \multicolumn{10}{|c|}{ Choroby układu krążenia } \\
\hline Sz & 118 & 8 & 29 & 16,18 & 4,83 & 17 & 23,29 & 0,15 & $-0,60$ \\
\hline N & 118 & 7 & 23 & 12,94 & 4,43 & 13 & 19,66 & 0,44 & $-0,76$ \\
\hline Z & 118 & 7 & 26 & 14,34 & 5,84 & 14 & 34,12 & 0,41 & $-0,91$ \\
\hline D & 117 & 8 & 25 & 15,51 & 4,22 & 15 & 17,84 & 0,06 & $-0,66$ \\
\hline UG & 118 & 7 & 24 & 13,74 & 4,48 & 14 & 20,07 & 0,13 & $-0,95$ \\
\hline UW & 118 & 9 & 29 & 17,23 & 4,71 & 16 & 22,14 & 0,33 & $-0,87$ \\
\hline A & 118 & 7 & 28 & 18,13 & 4,18 & 18 & 17,50 & $-0,06$ & 0,09 \\
\hline P & 118 & 8 & 32 & 21,81 & 5,33 & 23 & 28,40 & $-0,65$ & $-0,06$ \\
\hline \multicolumn{10}{|c|}{ Reumatoidalne zapalenie stawów } \\
\hline Sz & 74 & 8 & 31 & 16,94 & 5,13 & 16 & 26,30 & 0,28 & $-0,75$ \\
\hline N & 74 & 7 & 29 & 13,85 & 4,71 & 13 & 22,18 & 0,83 & 0,60 \\
\hline Z & 74 & 7 & 27 & 14,23 & 4,73 & 14,50 & 22,37 & 0,24 & $-0,53$ \\
\hline D & 72 & 8 & 31 & 16,71 & 5,74 & 15,50 & 32,97 & 0,46 & $-0,43$ \\
\hline UG & 74 & 7 & 30 & 16,59 & 4,25 & 16 & 18,08 & 0,51 & 0,82 \\
\hline UW & 74 & 8 & 31 & 16,90 & 5,42 & 17 & 29,40 & 0,22 & $-0,74$ \\
\hline A & 74 & 9 & 25 & 18,30 & 4,48 & 19 & 20,10 & $-0,50$ & $-0,57$ \\
\hline P & 74 & 9 & 32 & 22,53 & 6,30 & 23 & 39,73 & $-0,31$ & $-0,74$ \\
\hline
\end{tabular}

\section{Rzetelność i stabilność kwestionariusza}

W ustalaniu wskaźników rzetelności narzędzia posłużono się metodą zgodności wewnętrznej a Cronbacha i podziału połówkowego Guttmana. Wskaźniki te obliczono zarówno dla całego kwestionariusza, jak również dla poszczególnych podskal (tab. 6).

Tabela 6

Wartości współczynników $\alpha$ Cronbacha i Guttmana dla poszczególnych podskal KRP

$(\mathrm{N}=940)$

\begin{tabular}{|c|c|c|}
\hline Podskala & $\alpha$ Cronbacha & Guttmana \\
\hline Sz & 0,80 & 0,75 \\
\hline N & 0,81 & 0,76 \\
\hline Z & 0,83 & 0,70 \\
\hline D & 0,78 & 0,74 \\
\hline UG & 0,83 & 0,77 \\
\hline UW & 0,80 & 0,75 \\
\hline A & 0,80 & 0,75 \\
\hline P & 0,88 & 0,82 \\
\hline
\end{tabular}


Uzyskane współczynniki rzetelności są wysokie, co świadczy o zadowalającej spójności wyodrębnionych podskal KRP. Oszacowano również wskaźnik stabilności bezwzględnej (stałości) na podstawie przeprowadzonego dwukrotnie badania tych samych osób (test - retest) w odstępnie dwóch tygodni $(\mathrm{N}=111)$, uzyskując współczynniki korelacji w przedziale 0,57-0,94. Najniższa korelacja dotyczy skali niepokoju i szoku (tab. 7). Otrzymane dane wskazują na satysfakcjonującą stabilność narzędzia.

Tabela 7

Współczynniki korelacji: test - retest $(\mathrm{N}=111)$

\begin{tabular}{|c|c|}
\hline Podskala & r Pearsona \\
\hline Sz & $0,57^{*}$ \\
\hline N & $0,66^{*}$ \\
\hline Z & $0,92^{* *}$ \\
\hline D & $0,79^{* *}$ \\
\hline UG & $0,82^{* *}$ \\
\hline UW & $0,88^{* *}$ \\
\hline A & $0,94^{* *}$ \\
\hline P & $0,81^{* *}$ \\
\hline
\end{tabular}

${ }^{*} \mathrm{p}<0,05 ;{ }^{* *} \mathrm{p}<0,01$.

\section{Trafność kwestionariusza}

Ustalenie właściwości psychometrycznych narzędzia obejmowało również określenie jego trafności: teoretycznej, zbieżnej i kryterialnej. Za trafnością teoretyczną przemawiają następujące ustalenia. Po pierwsze, złożoność i wielowymiarowość zjawiska przystosowania do życia po nabyciu trwałych uszkodzeń w zdrowiu czy sprawności została potwierdzona wynikami analizy czynnikowej. Po drugie, budowa kwestionariusza została oparta na konkretnej konceptualizacji reakcji przystosowawczych, zawartej w założeniach modelu psychospołecznej adaptacji do życia z niepełnosprawnością i chorobą przewlekłą H. Livneha i R.F. Antonaka.

Natomiast, trafność zbieżną określono na podstawie związków KRP $\mathrm{z}$ innymi narzędziami mierzącymi przystosowanie po nabyciu ograniczeń w zdrowiu i sprawności dotychczas wykorzystywanymi na gruncie polskim, jak: Kwestionariusz Reintegracji do Normalnego Życia (KRNŻ), Kwestionariusz Przystosowania Psychospołecznego (PACI) F.C. Shontza i S.L. Finka oraz Inwentarz HPI do określenia sytuacji psychospołecznej osób z niepełnosprawnością i chorobą przewlekłą. 
O trafności zbieżnej kwestionariusza świadczy umiarkowana i istotna statystycznie korelacja składających się na niego podskal z uwzględnionymi skalami (tab. 8-12).

Tabela 8

Związki korelacyjne między KRP i KRNŻ (w całej przebadanej próbie: N = 940)

\begin{tabular}{|l|c|c|c|c|c|c|c|c|c|c|c|}
\hline KRP & I & II & III & IV & V & VI & VII & VIII & IX & X & XI \\
\hline Sz & $-0,09$ & 0,05 & 0,03 & 0,04 & 0,05 & 0,02 & 0,05 & 0,06 & 0,04 & 0,05 & 0,05 \\
\hline N & 0,02 & 0,05 & 0,04 & $0,38^{*}$ & 0,07 & 0,06 & 0,08 & 0,07 & $-0,15^{*}$ & $-0,41^{*}$ & $-0,38^{*}$ \\
\hline Z & $0,15^{*}$ & 0,05 & $0,14^{*}$ & $0,20^{*}$ & 0,06 & $0,29^{*}$ & 0,10 & $0,12^{*}$ & $0,18^{*}$ & $0,11^{*}$ & $0,51^{*}$ \\
\hline D & 0,01 & 0,04 & 0,01 & 0,07 & 0,04 & 0,01 & $-0,40^{*}$ & 0,05 & 0,04 & 0,05 & 0,04 \\
\hline UG & $-0,01$ & 0,01 & 0,02 & $0,41^{*}$ & $-0,14^{*}$ & $-0,23^{*}$ & $-0,21^{*}$ & $-0,11^{*}$ & $-0,29^{*}$ & $-0,11^{*}$ & $-0,12^{*}$ \\
\hline UW & 0,00 & 0,01 & 0,02 & 0,02 & 0,04 & $-0,21^{*}$ & $-0,24^{*}$ & $-0,22^{*}$ & $-0,31^{*}$ & $-0,21^{*}$ & $-0,22^{*}$ \\
\hline A & $0,14^{*}$ & $0,12^{*}$ & 0,11 & $-0,12^{*}$ & $0,24^{*}$ & $0,22^{*}$ & $0,32^{*}$ & $0,11^{*}$ & $0,21^{*}$ & $0,14^{*}$ & $0,25^{*}$ \\
\hline P & $0,28^{*}$ & $0,49^{*}$ & $0,36^{*}$ & $-0,53^{*}$ & $0,39^{*}$ & $0,31^{*}$ & $0,46^{*}$ & $0,33^{*}$ & $0,57^{*}$ & $0,31^{*}$ & $-0,04$ \\
\hline
\end{tabular}

${ }^{*} \mathrm{p}<0,05$.

I - (Poruszam się w obrębie mojej okolicy - jeśli mam taką ochotę).

II - (Poruszam się wśród ludzi - jeśli mam na to ochotę).

III - (Jestem w stanie udać się na wycieczkę poza miasto - jeśli mam taką ochotę).

IV - (Jestem wygodny, potrzebuję opieki).

V - (Spędzam większość dni zajęty aktywną pracą).

VI - (Jestem w stanie uczestniczyć w aktywnej rekreacji).

VII - (Uczestniczę w życiu towarzyskim z rodziną, przyjaciółmi, znajomymi z pracy).

VIII - (Przyjmuję taką rolę w mojej rodzinie, która zaspokaja potrzeby moje i innych członków rodziny).

IX - (Generalnie czuję się dobrze w relacjach międzyosobowych).

$\mathrm{X}$ - (Generalnie jestem zadowolony z siebie, jeśli jestem w towarzystwie innych).

XI - (Czuję, że mogę uczestniczyć we wszystkim, cokolwiek się zdarzy).

Zgodnie z oczekiwaniami, uzyskano pozytywne korelacje między reakcjami typowo adaptacyjnymi: akceptacją poznawczą (A) i emocjonalnobehawioralnym przystosowaniem (P) a poszczególnymi wymiarami KRNŻ, odnoszącymi się do różnych aspektów przystosowania środowiskowego i społecznego, przy jednocześnie otrzymanych negatywnych korelacjach w przypadku reakcji z założenia nieadaptacyjnych. Uwagę zwraca pozytywny charakter związku między niektórymi wymiarami KRNŻ a zaprzeczaniem. Przypuszczalnie reakcja ta pełni tutaj określone funkcje adaptacyjne, współtowarzysząc przekonaniu o nieograniczonych możliwościach uczestnictwa we wszelakich aspektach życia społecznego, niezależnie od czasu i okoliczności. 
Tabela 9

Związki korelacyjne między KRP i PACI

(w próbie badanych z urazem rdzenia kręgowego i po amputacji kończyn dolnych: $\mathrm{N}=317$ )

\begin{tabular}{|l|c|c|c|c|c|c|c|c|}
\hline \multicolumn{1}{|c|}{ PACI } & $\mathrm{Sz}$ & $\mathrm{N}$ & $\mathrm{Z}$ & $\mathrm{D}$ & $\mathrm{UG}$ & $\mathrm{UW}$ & $\mathrm{A}$ & $\mathrm{P}$ \\
\hline $\mathrm{K}$ & $-0,01$ & $-0,05$ & 0,04 & $-0,03$ & 0,02 & $-0,24^{*}$ & 0,12 & 0,19 \\
\hline ZN & $-0,05$ & 0,05 & $-0,15$ & $-0,14$ & $-0,22^{*}$ & $-0,01$ & $0,32^{*}$ & $0,23^{*}$ \\
\hline PA & 0,02 & 0,06 & $0,28^{*}$ & $-0,01$ & $-0,13$ & 0,09 & $-0,12$ & $0,22^{*}$ \\
\hline OWZ & $-0,09$ & $-0,12$ & $0,22^{*}$ & $-0,27^{*}$ & $-0,23^{*}$ & 0,11 & $0,33^{*}$ & 0,24 \\
\hline Motywacja (M) & $-0,10$ & $-0,24^{*}$ & 0,18 & $-0,24^{*}$ & $-0,21^{*}$ & 0,12 & $0,29^{*}$ & $0,39^{*}$ \\
\hline D & 0,12 & $-0,14$ & $-0,38^{*}$ & $-0,32^{*}$ & $-0,46^{*}$ & $-0,44^{*}$ & $0,33^{*}$ & $0,34^{*}$ \\
\hline AR & $-0,09$ & 0,07 & $-0,06$ & $-0,35^{*}$ & $-0,46^{*}$ & $-0,44^{*}$ & $0,23^{*}$ & $0,33^{*}$ \\
\hline UI & 0,03 & $0,22^{*}$ & $0,41^{*}$ & $0,34^{*}$ & $0,35^{*}$ & $-0,39^{*}$ & $-0,11$ & $-0,19$ \\
\hline SU & $-0,09$ & $-0,08$ & $-0,11$ & $-0,33^{*}$ & $-0,37^{*}$ & $-0,47^{*}$ & $0,25^{*}$ & $0,36^{*}$ \\
\hline $\begin{array}{l}\text { Przystosowanie } \\
\text { społeczne (PS) }\end{array}$ & $-0,10$ & $-0,19$ & $-0,33^{*}$ & $-0,34^{*}$ & $-0,42^{*}$ & $-0,44^{*}$ & $0,33^{*}$ & $0,35^{*}$ \\
\hline AK & $-0,34^{*}$ & $-0,32^{*}$ & $-0,35^{*}$ & $-0,44^{*}$ & $-0,48^{*}$ & $-0,36^{*}$ & $0,67^{*}$ & $0,48^{*}$ \\
\hline E & $0,18^{*}$ & $-0,49^{*}$ & $-0,55^{*}$ & $-0,39^{*}$ & $0,55^{*}$ & $-0,26^{*}$ & $0,44^{*}$ & $0,33^{*}$ \\
\hline PO & $-0,48^{*}$ & $-0,38^{*}$ & $-0,45^{*}$ & $-0,67^{*}$ & $-0,55^{*}$ & $-0,23^{*}$ & $0,55^{*}$ & 0,19 \\
\hline RF & $0,14^{*}$ & $0,45^{*}$ & 0,11 & $0,23^{*}$ & $0,32^{*}$ & $0,30^{*}$ & $-0,38$ & $-0,49^{*}$ \\
\hline $\begin{array}{l}\text { Przystosowanie } \\
\text { Osobiste (PO) }\end{array}$ & $-0,25^{*}$ & $-0,35^{*}$ & $-0,27^{*}$ & $-0,57^{*}$ & $-0,49^{*}$ & $-0,34^{*}$ & $0,59^{*}$ & $0,50^{*}$ \\
\hline
\end{tabular}

${ }^{*} \mathrm{p}<0,05$.

K - Kooperatywność; ZN - Zrozumienie niepełnosprawności; PA - Poziom aktywności; OWZ Ocena własnych zdolności; D - Dominacja; AR - Akceptacja przez rodzinę; UI - Uzależnienie od innych; SU - Stosunek uczuciowy; AK - Akceptacja kalectwa; E - Emocjonalność; PO - Poznawcza organizacja; RF - Reakcje na frustracje.

Ustalone związki korelacyjne między reakcjami przystosowawczymi ujętymi z pomocą KRP oraz przystosowaniem mierzonym PACI są zgodne z przewidywanymi. Wprawdzie oczekiwano większej siły powiązań, zarówno w odniesieniu do korelacji pozytywnych jak i negatywnych, niemniej ustalony ich kierunek pozwala stwierdzić o zbieżności zmiennych mierzących poszczególne aspekty przystosowania u osób z nabytą niepełnosprawnością ruchową.

Otrzymane związki korelacyjne między reakcjami przystosowawczymi a nasileniem problemów w sferze osobowościowej, rodzinnej, społecznej i zajęciowej są zgodne $\mathrm{z}$ przewidywaniami. We wszystkich trzech grupach badanych: $z$ urazem rdzenia kręgowego, cukrzycą i chorobami układu krążenia zaznaczyły się pozytywne korelacje między reakcjami nieprzystosowawczymi a nasileniem problemów w uwzględnionych obszarach oraz negatywne związki w obrębie pomyślnego reagowania adaptacyjnego (w 
postaci akceptacji i przystosowania) i natężenia mierzonych trudności. Należy przy tym podkreślić, iż ustalone związki utrzymują się głównie na poziomie umiarkowanym.

Tabela 10 Związki korelacyjne między KRP i HPI w próbie badanych z urazem rdzenia kręgowego ( $N=155$, cukrzycą $N=154$ i chorobami układu krążenia $N=118)$

\begin{tabular}{|c|c|c|c|c|c|}
\hline KRP & $\begin{array}{c}\text { Sfera } \\
\text { osobowościowa }\end{array}$ & $\begin{array}{c}\text { Sfera } \\
\text { rodzinna }\end{array}$ & $\begin{array}{c}\text { Sfera } \\
\text { społeczna }\end{array}$ & $\begin{array}{c}\text { Sfera } \\
\text { zajęciowa }\end{array}$ & $\begin{array}{l}\text { Wynik } \\
\text { ogólny }\end{array}$ \\
\hline \multicolumn{6}{|c|}{ Uraz rdzenia kręgowego } \\
\hline $\mathrm{Sz}$ & 0,03 & 0,01 & 0,14 & 0,08 & 0,12 \\
\hline $\mathrm{N}$ & $0,26^{*}$ & $0,35^{*}$ & $0,22^{*}$ & $0,38^{*}$ & $0,24^{*}$ \\
\hline$Z$ & $0,32^{*}$ & $-0,22^{*}$ & $0,38^{*}$ & $0,34^{*}$ & $0,35^{*}$ \\
\hline $\mathrm{D}$ & $0,36^{*}$ & $0,34^{*}$ & $0,32^{*}$ & $0,46^{*}$ & $0,32^{*}$ \\
\hline UG & $0,27^{*}$ & $0,43^{*}$ & $0,35^{*}$ & $0,29^{*}$ & $0,42^{*}$ \\
\hline UW & $0,44^{*}$ & $0,32^{*}$ & $0,47^{*}$ & $0,22^{*}$ & $0,46^{*}$ \\
\hline $\mathrm{A}$ & $-0,42^{*}$ & $-0,43^{*}$ & $-0,39^{*}$ & $-0,42^{*}$ & $-0,56^{*}$ \\
\hline $\mathrm{P}$ & $-0,29^{*}$ & $-0,39^{*}$ & $-0,49^{*}$ & $-0,56^{*}$ & $-0,50^{*}$ \\
\hline \multicolumn{6}{|c|}{ Cukrzyca } \\
\hline $\mathrm{Sz}$ & 0,15 & 0,12 & 0,16 & 0,15 & 0,14 \\
\hline $\mathrm{N}$ & $0,26^{*}$ & 0,11 & $0,27^{*}$ & $0,38^{*}$ & $0,27^{*}$ \\
\hline$Z$ & $0,38^{*}$ & 0,11 & $0,26^{*}$ & 0,14 & $0,25^{*}$ \\
\hline $\mathrm{D}$ & $0,41^{*}$ & $0,31^{*}$ & 0,14 & $0,37^{*}$ & $0,32^{*}$ \\
\hline UG & $0,36^{*}$ & $0,48^{*}$ & $-0,12$ & $0,44^{*}$ & $0,45^{*}$ \\
\hline UW & $0,25^{*}$ & $0,45^{*}$ & $-0,10$ & $0,36^{*}$ & $0,42^{*}$ \\
\hline $\mathrm{A}$ & $-0,43^{*}$ & $-0,55^{*}$ & $-0,53^{*}$ & $-0,59^{*}$ & $-0,51^{*}$ \\
\hline $\mathrm{P}$ & $-0,41^{*}$ & $-0,53^{*}$ & $-0,56^{*}$ & $-0,45^{*}$ & $-0,52^{*}$ \\
\hline \multicolumn{6}{|c|}{ Choroby układu krążenia } \\
\hline $\mathrm{Sz}$ & $0,26^{*}$ & $-0,14$ & $0,20^{*}$ & $0,24^{*}$ & 0,11 \\
\hline $\mathrm{N}$ & 0,19 & 0,10 & $0,38^{*}$ & $0,26^{*}$ & $0,26^{*}$ \\
\hline $\mathrm{Z}$ & $0,36^{*}$ & 0,15 & $-0,43^{*}$ & $0,34^{*}$ & $0,42^{*}$ \\
\hline $\mathrm{D}$ & $0,46^{*}$ & $-0,14$ & $0,45^{*}$ & $0,36^{*}$ & $0,27^{*}$ \\
\hline UG & $0,57^{*}$ & $0,42^{*}$ & $0,53^{*}$ & $0,47^{*}$ & $0,44^{*}$ \\
\hline UW & $-0,51^{*}$ & $0,43^{*}$ & $0,64^{*}$ & $0,58^{*}$ & $0,51^{*}$ \\
\hline $\mathrm{A}$ & $-0,63^{*}$ & $-0,51^{*}$ & $-0,63^{*}$ & $-0,25^{*}$ & $-0,58^{*}$ \\
\hline $\mathrm{P}$ & $-0,56^{*}$ & $-0,48^{*}$ & $-0,53^{*}$ & $-0,43^{*}$ & $-0,48^{*}$ \\
\hline
\end{tabular}

${ }^{*} p<0,05$.

Sprawdzanie trafności zbieżnej obejmowało również analizy związków między reakcjami przystosowawczymi a akceptacją choroby wśród badanych chorujących przewlekle. Obliczono współczynniki korelacji zarówno dla całej grupy chorych, jak i w obrębie prób badanych z poszczególnymi rodzajami choroby przewlekłej (tab. 11). Akceptacja poznawcza (A) i emo- 
cjonalno-behawioralna $(\mathrm{P})$ mierzona kwestionariuszem KRP pozytywnie (na poziomie wysokim lub umiarkowanym) koreluje $\mathrm{z}$ akceptacją chorobą ustalaną za pomocą skali AIS w poszczególnych grupach chorujących badanych.

Tabela 11

Związki korelacyjne między KRP i AIS u badanych z chorobą przewlekłą

\begin{tabular}{|l|c|c|c|c|c|c|c|c|}
\hline \multicolumn{1}{|c|}{ Akceptacja choroby } & $\mathrm{Sz}$ & $\mathrm{N}$ & $\mathrm{Z}$ & $\mathrm{D}$ & $\mathrm{UG}$ & $\mathrm{UW}$ & $\mathrm{A}$ & $\mathrm{P}$ \\
\hline $\begin{array}{l}\text { Cała grupa chorych } \\
(\mathrm{N}=625)\end{array}$ & $-0,23^{*}$ & $-0,34^{*}$ & $-0,56^{*}$ & $-0,41^{*}$ & $-0,55^{*}$ & $-0,34^{*}$ & $0,71^{*}$ & $0,59^{*}$ \\
\hline Chorzy z SM (N = 150) & $-0,41^{*}$ & $-0,47^{*}$ & $-0,55^{*}$ & $-0,45^{*}$ & $-0,46^{*}$ & $-0,47^{*}$ & $0,61^{*}$ & $0,41^{*}$ \\
\hline $\begin{array}{l}\text { Chorzy z cukrzycą } \\
(\mathrm{N}=154)\end{array}$ & $-0,11$ & $-0,39^{*}$ & $-0,47^{*}$ & $-0,14$ & $-0,23^{*}$ & $-0,21^{*}$ & $0,62^{*}$ & $0,46^{*}$ \\
\hline $\begin{array}{l}\text { Chorzy z chorobą } \\
\text { nowotworową } \\
(\mathrm{N}=132)\end{array}$ & $-0,37^{*}$ & $-0,58^{*}$ & $-0,48^{*}$ & $-0,43^{*}$ & $-0,49^{*}$ & $-0,52^{*}$ & $0,68^{*}$ & $0,54^{*}$ \\
\hline $\begin{array}{l}\text { Chorzy z chorobami } \\
\text { układu krążenia } \\
(\mathrm{N}=132)\end{array}$ & $-0,12$ & $0,23^{*}$ & $0,42^{*}$ & $-0,32^{*}$ & $-0,15$ & $-0,14$ & $0,67^{*}$ & $0,62^{*}$ \\
\hline $\begin{array}{l}\text { Chorzy } \\
\mathrm{z} \text { reumatoidalnym } \\
\text { zapaleniem stawów } \\
\text { (N = 117) }\end{array}$ & $-0,19$ & $-0,23^{*}$ & $-0,41^{*}$ & $-0,46^{*}$ & $-0,40^{*}$ & $-0,37^{*}$ & $0,64^{*}$ & $0,53^{*}$ \\
\hline
\end{tabular}

${ }^{*} \mathrm{p}<0,05$.

Tabela 12

Związki korelacyjne między KRP i Mini - MAC u badanych z chorobą nowotworową

$\mathrm{N}=132$

\begin{tabular}{|l|c|c|c|c|c|c|}
\hline KRP & $\begin{array}{c}\text { Zaabsor- } \\
\text { bowanie } \\
\text { lękowe }\end{array}$ & $\begin{array}{c}\text { Duch } \\
\text { walki }\end{array}$ & $\begin{array}{c}\text { Bezrad- } \\
\text { ność- } \\
\text { bezsil- } \\
\text { ność }\end{array}$ & $\begin{array}{c}\text { Pozytywne } \\
\text { wartościo- } \\
\text { wanie }\end{array}$ & $\begin{array}{c}\text { Styl } \\
\text { dekonstruk- } \\
\text { tywny }\end{array}$ & $\begin{array}{c}\text { Styl } \\
\text { konstruk- } \\
\text { tywny }\end{array}$ \\
\hline $\mathrm{Sz}$ & 0,12 & $-0,14$ & 0,11 & $-0,12$ & 0,12 & $-0,14$ \\
\hline $\mathrm{N}$ & $0,59^{*}$ & $-0,17$ & 0,11 & 0,16 & $0,48^{*}$ & $-0,19$ \\
\hline $\mathrm{Z}$ & $-0,13$ & $-0,46^{*}$ & $0,45^{*}$ & 0,13 & $0,36^{*}$ & $-0,32^{*}$ \\
\hline $\mathrm{D}$ & $0,48^{*}$ & 0,12 & $0,64^{*}$ & $-0,31^{*}$ & $0,61^{*}$ & $-0,44^{*}$ \\
\hline $\mathrm{UG}$ & $-0,16$ & $-0,57^{*}$ & $0,59^{*}$ & $-0,50^{*}$ & $0,40^{*}$ & $-0,51^{*}$ \\
\hline $\mathrm{UW}$ & $0,50^{*}$ & $-0,47^{*}$ & $0,48^{*}$ & $-0,49^{*}$ & $0,47^{*}$ & $-0,48^{*}$ \\
\hline $\mathrm{A}$ & $-0,30^{*}$ & $0,68^{*}$ & $-0,43^{*}$ & $0,68^{*}$ & $-0,72$ & $0,62^{*}$ \\
\hline $\mathrm{P}$ & $-0,22^{*}$ & $0,49^{*}$ & $-0,53^{*}$ & $0,44^{*}$ & $-0,63$ & $0,47^{*}$ \\
\hline
\end{tabular}

${ }^{*} \mathrm{p}<0,05$.

Do określenia trafności zbieżnej wykorzystano także narzędzie przeznaczone dla badanych z konkretną chorobą przewlekłą - Kwestionariusz Psy- 
chicznego Przystosowania do Choroby Nowotworowej (Mini - MAC) (tab. 12). Stwierdzona negatywna korelacja między podskalami określającymi niepomyślne przystosowanie do choroby i jej konsekwencji oraz podskalami odnoszącymi się do pożądanego reagowania adaptacyjnego potwierdza zakładaną zbieżność pomiaru obu uwzględnionych narzędzi. Nie ustalono jedynie, wbrew oczekiwaniom, istotnych związków między reakcją szoku a przystosowaniem $\mathrm{w}$ postaci zaabsorbowania lękowego czy bezradności bezsilności.

Trafność kryterialną ustalono na podstawie analizy związków KRP z narzędziami mierzącymi zmienne, które teoretycznie powinny korelować $\mathrm{z}$ wyodrębnionymi $\mathrm{w}$ tej skali reakcjami przystosowawczymi ze względu na podobieństwo treściowe lub z racji zakładanych $\mathrm{w}$ teorii funkcji reagowania adaptacyjnego. Kryterium zewnętrzne stanowiły następujące narzędzia: Test Orientacji Życiowej (LOT-R), Skala Uogólnionej Własnej Skuteczności (GSES), Inwentarz Stanu Lęku (STAI), Skala Depresji Becka, Skala Satysfakcji z Życia (SWLS), Skala Temporalnej Satysfakcji z Życia (TSŻ) oraz Kwestionariusz Orientacji Życiowej SOC-29 (tab. 13).

Tabela 13

Związki korelacyjne KRP i kryterium zewnętrznego ( $\mathrm{N}=940)$

\begin{tabular}{|c|c|c|c|c|c|c|c|c|c|c|c|c|}
\hline \multirow[b]{2}{*}{ KRP } & \multirow{2}{*}{$\begin{array}{l}\text { Opty- } \\
\text { mizm } \\
\text { dyspo- } \\
\text { zycjo- } \\
\text { nalny } \\
\text { (LOT-R) }\end{array}$} & \multirow{2}{*}{$\begin{array}{l}\text { Poczu- } \\
\text { cie } \\
\text { sku- } \\
\text { teczno- } \\
\text { ści } \\
\text { (GSES) }\end{array}$} & \multirow{2}{*}{$\begin{array}{l}\text { Lęk } \\
\text { jako } \\
\text { stan }\end{array}$} & \multirow{2}{*}{$\begin{array}{l}\text { De- } \\
\text { presja } \\
(\mathrm{SDB})\end{array}$} & \multirow{2}{*}{$\begin{array}{l}\text { Satys- } \\
\text { fakcja } \\
\text { z życia } \\
\text { (SWLS) }\end{array}$} & \multicolumn{3}{|c|}{$\begin{array}{c}\text { Temporalna } \\
\text { satysfakcja z życia } \\
(\mathrm{TSŻ})^{42}\end{array}$} & \multicolumn{4}{|c|}{$\begin{array}{l}\text { Poczucie koherencji } \\
\text { (SOC) }\end{array}$} \\
\hline & & & & & & PE & $\mathrm{T}$ & PY & PZR & PZ & PS & WO \\
\hline $\mathrm{Sz}$ & $-0,16$ & $-0,15$ & & & & & & & & & & \\
\hline $\mathrm{N}$ & $-0,31^{*}$ & $-0,23^{*}$ & $0,37^{*}$ & & & & & & & & & \\
\hline Z & $0,28^{*}$ & $0,34^{*}$ & & & & & & & & & & \\
\hline $\mathrm{D}$ & $-0,22$ & $-0,32^{*}$ & $0,32^{*}$ & $0,35^{*}$ & & & & & & & & \\
\hline UG & $-0,12$ & $-0,26^{*}$ & $0,19^{*}$ & $0,22^{*}$ & & & & & & & & \\
\hline UW & $-0,24^{*}$ & $0,42^{*}$ & $0,17^{*}$ & & & & & & & & & \\
\hline $\mathrm{A}$ & $0,59^{*}$ & $0,54^{*}$ & & & $0,37^{*}$ & $0,39 *$ & $0,30^{*}$ & $0,62^{*}$ & $0,29 *$ & $0,27^{*}$ & $0,24^{*}$ & $0,25^{*}$ \\
\hline $\mathrm{P}$ & $0,47^{*}$ & $0,52^{*}$ & & & $0,23^{*}$ & $0,40^{*}$ & $0,51^{*}$ & $0,47^{*}$ & $0,25^{*}$ & $0,31^{*}$ & $0,22^{*}$ & $0,24^{*}$ \\
\hline
\end{tabular}

${ }^{*} \mathrm{p}<0,05$.

Temporalna satysfakcja z życia (TSŻ): PE - Przeszłość, T - Teraźniejszość, PY - Przyszłość; Poczucie koherencji (SOC): PZR - Poczucie zrozu-

42 Uwzględniono wyniki z publikacji: S. Byra, Temporalność w przystosowaniu do życia $z$ niepetnosprawnością kobiet $i$ mężczyzn niepetnosprawnych ruchowo, [w:] Zdrowa szkoła - zdrowy uczeń. Między teorią a praktyką. Wybrane zagadnienia, red. J. Kirenko, Lublin 2010 (otrzymane za pomocą eksperymentalnej wersji KRP wśród kobiet $\mathrm{z}$ nabytą niepełnosprawnością ruchową, $\mathrm{N}=50$ ). 
miałości, PZ - Poczucie zaradności, PS - Poczucie sensowności, WO - wynik ogólny.

Zgodnie z przewidywaniami, skale optymizmu dyspozycjonalnego i przekonania o własnej skuteczności zaradczej pozytywnie korelują z akceptacją poznawczą (A) i emocjonalno-behawioralną $(\mathrm{P})$ oraz negatywnie $\mathrm{z}$ reakcjami nieprzystosowawczymi (poza reakcją szoku, która nie wykazuje tutaj znaczącego powiązania). Istotne do podkreślenia jest, iż przekonanie o posiadaniu zdolności do skutecznego zmagania się z problemami wykazuje pozytywne powiązanie $\mathrm{z}$ reakcją $\mathrm{w}$ postaci wrogości skierowanej na zewnątrz. Ujawnianiu wrogości w stosunku do innych towarzyszy zatem przekonanie, iż jedynie samodzielnie można poradzić sobie w sposób skuteczny z napotykanymi przeszkodami, trudnościami. Lęk rozumiany jako stan przejściowy i warunkowany sytuacyjnie jest zbieżny z założeniami pozytywnie, korelując ze skalą Niepokoju oraz skalami typowo nieadaptacyjnymi w postaci Depresji, Uwewnętrznionego gniewu i Uzewnętrznionej wrogości. Ustalono ponadto, iż depresja mierzona Skalą Depresji Becka pozostaje w dodatniej korelacji z reakcją depresji i uwewnętrznionego gniewu identyfikowanych za pomocą KRP, niemniej spodziewano się $\mathrm{w}$ tym obszarze silniejszych powiązań. Wychodząc z założenia o istnieniu ścisłych i pozytywnych powiązań między pożądanymi reakcjami przystosowawczymi odpowiedzialnymi za pomyślny przebieg procesu adaptacji a ogólnym zadowoleniem z życia, skorelowano te zmienne $\mathrm{w}$ niniejszych analizach. Otrzymane rezultaty potwierdzają przewidywane związki, jednak są one nieco silniejsze w sytuacji przyjęcia temporalnej perspektywy satysfakcji z życia. Również ustalenie dodatnich korelacji w zakresie reakcji adaptacyjnych i poczucia koherencji (zarówno wymiaru ogólnego, jak i elementów składowych) może wskazywać na istotną zbieżność merytoryczną analizowanych tutaj zmiennych.

\section{Opis narzędzia i obliczanie wyników}

Prezentowany Kwestionariusz Reakcji Przystosowawczych (KRP) jest wielowymiarowym narzędziem mierzącym osobiste reakcje na nabycie niepełnosprawności lub choroby przewlekłej. Liczba twierdzeń jest identyczna jak $\mathrm{w}$ wersji oryginalnej kwestionariusza i wynosi 60. Każde twierdzenie oceniane jest na 4-stopniowej skali. Otrzymane wyniki sumuje się, a uzyskana wartość wskazuje na nasilenie danej reakcji u badanego. Kwestionariusz składa się z 8 podskal wyrażających poszczególne kategorie reakcji przysto- 
sowawczych: Szok, Niepokój, Zaprzeczanie, Depresja, Uwewnętrzniony gniew, Uzewnętrzniona wrogość, Akceptacja, Przystosowanie. Wyższy wynik $\mathrm{w}$ danej podskali wskazuje na większą częstotliwość ujawniania określonej reakcji przystosowawczej. Podzielenie wyniku podskali przez liczbę składających się na nią twierdzeń umożliwia porównywanie nasilenia poszczególnych sposobów reagowania u osób badanych.

\section{Podsumowanie}

Podsumowując, przeprowadzone analizy nad właściwościami psychometrycznymi polskiej wersji Reactions to Impairment and Disability Inventory (RIDI) w postaci Kwestionariusza Reakcji Przystosowawczych pozwalają twierdzić o jego zadowalającej rzetelności, stabilności i trafności. Choć ładunki czynnikowe $\mathrm{w}$ niektórych podskalach są niższe niż się spodziewano, strukturę wewnętrzną narzędzia można uznać za spójną, zbieżną z przyjętą w oryginalnej wersji kwestionariusza.

Narzędzie umożliwia wielowymiarowy pomiar adaptacji $\mathrm{w}$ postaci przystosowawczych i nieprzystosowawczych reakcji, będąc użytecznym $\mathrm{w}$ badaniach nad ich różnorodnymi konfiguracjami u osób $\mathrm{z}$ nabytymi ograniczeniami $\mathrm{w}$ zdrowiu i sprawności. Wprawdzie prezentowany kwestionariusz został opracowany i sprawdzony pod względem psychometrycznym wśród badanych z nabytą niepełnosprawnością i chorobą przewlekłą, zdaniem H. Livneha i R.F. Antonaka43, w większym zakresie może mieć zastosowanie $\mathrm{w}$ odniesieniu do niepełnosprawności fizycznej. Wydaje się więc zasadne dokładniejsze przeanalizowanie $\mathrm{w}$ przyszłych badaniach właściwości tego narzędzia w kontekście wskazanej grupy niepełnosprawności. Nie przeanalizowano $\mathrm{z}$ użyciem polskiej wersji kwestionariusza, a tym samym nie rozstrzygnięto, istotnych kwestii merytorycznych odnoszących się do struktury ujawnianych reakcji przystosowawczych, m.in. ich hierarchiczności, niezależności reakcji adaptacyjnych i nieadaptacyjnych, temporalnego wymiaru reagowania $\mathrm{w}$ długofalowym procesie zmagania się z nabytymi ograniczeniami. Stanowią one podstawę kolejnych analiz empirycznych, których wyniki mogą dostarczyć wyjaśnienia m.in. zaznaczającej się obecnie słabszej spójności wewnętrznej podskali Szoku i Depresji.

Kwestionariusz przeznaczony jest głównie do celów badawczych, jednak może stanowić również uzupełniające narzędzie diagnostyczne i kliniczne. Konstrukcja narzędzia pozwala ponadto na wykorzystywanie jego fragmen-

${ }^{43}$ H. Livneh, R.F. Antonak, Reactions to impairment. 
tów, np. podskal Akceptacji i Przystosowania, traktowanych łącznie jako wskaźniki pozytywnego przystosowania ${ }^{44}$.

\section{BIBLIOGRAFIA}

Bishop M., Quality of life and psychosocial adaptation to chronic illness and acquired disability: Preliminary analysis of a conceptual and theoretical synthesis, Rehabilitation Counseling Bulletin, 2005a, 48(3).

Bishop M., Quality of life and psychosocial adaptation to chronic illness and acquired disability. A conceptual and theoretical synthesis, Journal of Rehabilitation, 2005b, 71(1).

Byra S., Ewolucja pogladów dotyczacych przystosowania do życia osób z nabytą niepetnosprawnością, Człowiek - Niepełnosprawność - Społeczeństwo, 2006, 2(4).

Byra S., H. Lioneha $i$ R. Antonaka koncepcja adaptacji do życia z niepetnosprawnościa, Niepełnosprawność i Rehabilitacja, 2008, 4.

Byra S., Temporalność w przystosowaniu do życia z niepetnosprawnościa kobiet i mężczyzn niepetnosprawnych ruchowo, [w:] Zdrowa szkota - zdrowy uczeń. Między teoria a praktyka. Wybrane zagadnienia, red. J. Kirenko, Wydawnictwo NeuroCentrum, Lublin 2010.

Byra S., Przystosowanie do życia z niepetnosprawnościa ruchowa i choroba przewlekła. Struktura i uwarunkowania, Wydawnictwo UMCS, Lublin 2012.

Dipeolu A., Reardon R., Sampson J., Burkhead J., The relationship between dysfunctional career thoughts and adjustment to disability in college students with learning disabilities, Journal of Career Assessment, 2002, 10(4).

Keany K.C., Glueckauf R.L., Disability and value changes: An overview and analysis of acceptance of loss theory, Rehabilitation Psychology, 1993, 38(2).

Kendall E., Buys N., An integrated model of psychosocial adjustment following acquired disability, Journal of Rehabilitation, 1998, 64(3).

Kirenko J., Psychospołeczne przystosowanie osób z paraplegia, Wydawnictwo UMCS, Lublin 1991.

Kirenko J., Niektóre uwarunkowania psychospołecznego funkcjonowania osób z uszkodzeniem rdzenia kregowego, Wydawnictwo UMCS, Lublin 1995.

Krause J.S., Changes in adjustment after spinal cord injury: A 20-year longitudinal study, Rehabilitation Psychology, 1998, 43(1).

Livneh H., Psychosocial adaptation to chronic illness and disability: A conceptual framework, Rehabilitation Counseling Bulletin, 2001, 44(1).

Livneh H., Antonak R.F., Reactions to disability: An empirical investigation of their nature and structure, Journal of Applied Rehabilitation Counseling, 1990, 21(4).

Livneh H., Antonak R.F., Temporal structure of adaptation to disability, Rehabilitation Counseling Bulletin, 1991, 34.

Livneh H., Antonak R.F., Psychosocial adaptation to chronic illness and disability, Aspen Publishers, Gaithersburg 1997.

Livneh H., Antonak R.F., Gerhardt J., Psychosocial adaptation to amputation: the role of sociodemographic variables, disability related factors and coping strategies, International Journal of Rehabilitation Research, 1999, 22(1).

44 Zob. H. Livneh, E. Martz, Coping strategies and resources as predictors of psychosocial adaptation, s. 334 . 
Livneh H., Martz E., Wilson L.M., Denial and perceived visibility as predictors of adaptation to disability among college students, Journal of Vocational Rehabilitation, 2001, 16(2).

Livneh H., Wilson L.M., Coping strategies as predictors and mediators of disability-related variables and psychosocial adaptation, Rehabilitation Counseling Bulletin, 2003, 46(1).

Livneh H., Lott S.M., Antonak R.F., Patterns of psychosocial adaptation to chronic illness and disability: a cluster analytic approach, Psychology Health and Medicine, 2004, 9(4).

Livneh H., Antonak R.F., Psychosocial adaptation to chronic illness and disability: A primer for counselors, Journal of Counseling and Development, 2005, 83(1).

Livneh H., Parker R., Psychological adaptation to disability: Perspectives from chaos and complexity theory, Rehabilitation Counseling Bulletin, 2005, 49(1).

Livneh H., Martz E., Psychosocial adaptation to spinal cord injury: A dimensional perspective, Psychological Reports, 2005, 97(2).

Livneh H., Martz E., Bodner T., Psychosocial adaptation to chronic illness and disability: A preliminary study of is factorial structure, Journal of Clinical Psychology in Medical Settings, 2006, 13(3).

Livneh H., Antonak R.F., Reactions to impairment and disability inventory users' manual unpublished manuscript 2008.

Livneh H., Martz E., Coping strategies and resources as predictors of psychosocial adaptation among people with spinal cord injury, Rehabilitation Psychology, 2014, 59(3).

Lustig D., The adjustment process for individuals with spinal cord injury: The impact of perceived pre-morbid sense of coherence, Rehabilitation Counseling Bulletin, 2005, 48(1).

Martz E., Invisibility of disability and work experience as predictors of employment among community college students with disabilities, Journal of Vocational Rehabilitation, 2003, 18(3).

Martz E., Do post-traumatic stress symptoms predict reactions of adaptation to disability after a sudden-onset spinal cord injury? International Journal of Rehabilitation Research, 2004a, 27(3).

Martz E., A one - year follow-up study on psychosocial adaptation of college students with disabilities, Journal of Vocational Rehabilitation, 2004b, 21(1).

Martz E., Do Reactions of Adaptation to Disability Influence the Fluctuation of Future Time Orientation Among Individuals with Spinal Cord Injuries? Rehabilitation Counseling Bulletin, 2004c, 47(2).

Martz E., Associations and predictors of posttraumatic stress-levels according to person-related, disability-related and trauma-related variables among individuals with spinal cord injuries, Rehabilitation Psychology, 2005, 50(2).

Martz, E., Livneh, H., Turpin, J., Locus of control orientation and acceptance of disability, Journal of Applied Rehabilitation Counseling, 2000, 31(3).

Martz E., Roessler R., Livneh H., Responses to insulin reactions and long-term adaptation to diabetes, Journal of Rehabilitation, 2002, 68(2).

Martz E., Livneh H., Priebe M., Wuermser L.A., Ottomanelli L., Predictors of psychosocial adaptation among people with spinal cord injury or disorder, Archives of Physical Medicine and Rehabilitation, 2005, 86(6).

Martz E., Livneh H., Do posttraumatic reactions predict future time perspective among people with insulin-dependent diabetes mellitus? Rehabilitation Counseling Bulletin, 2007, $50(2)$.

Martz E., Bodner T., Livneh H., Coping as moderator of disability and psychosocial adaptation among vietnam theater veterans, Journal of Clinical Psychology, 2009, 65(1). 
Martz E., Livneh H., Grontkovsky S.T., Stokic D.S., Psychosocial responses to spinal cord injury as predictors of pressure scores, International Journal of Clinical and Health Psychology, 2010, 10(2).

Meyer J. M., Kashubeck-West S., Well-being of individuals with late-deafness, Rehabilitation Psychology, 2013, 58(2).

Molton I. R., Stoelb B. L., Jensen M. P., Ehde D. M., Raichle K. A., Cardenas D. D., Psychosocial factors and adjustment to chronic pain in spinal cord injury: Replication and crossvalidation, Journal of Rehabilitation Research and Development, 2009, 46(1).

Psarra E., Kleftaras G., Adaptation to physical disabilities: The role of meaning in life and depression, The European Journal of Counseling Psychology, 2013, 2(1).

Schönberger M., Ponsford J., McKay A., Wong D., Spitz G., Harrington H., Mealings M., Development and predictors of psychological adjustment during the course of communitybased rehabilitation of traumatic brain injury: A preliminary study, Neuropsychological Rehabilitation: An International Journal, 2014, 24(2).

Treharne G.J., Lyons A.C., Booth D.A., Mason S.R., Kitas G.D., Reactions to disability in patients with early versus established rheumatoid arthritis, Scandinavian Journal of Rheumatology 2004, 33(1). 